PONTIFÍCIA UNIVERSIDADE CATÓLICA DO RIO DE JANEIRO

\author{
O Marketing Interno como Ferramenta de \\ Implementação e Gestão de um Programa de \\ Diversidade.
}

Brenda dos Santos Pravato

Trabalho de Conclusão de Curso

Centro de CIÊnCIAS SOCIAIS - CCS

DEPARTAMENTO DE AdMINISTRAÇÃO

Graduação em Administração de Empresas 


\section{O Marketing Interno como Ferramenta de Implementação e Gestão de um Programa de Diversidade}

Estudo de caso do programa de diversidade da Ball Corporation.

Trabalho de Conclusão de Curso

Trabalho de Conclusão de Curso, apresentado ao programa de graduação em Administração da PUC-Rio como requisito parcial para a obtenção do título de graduação em Administração.

Orientador(a): Marcus Wilcox Hemais 


\section{Agradecimentos}

Ao meu irmão, que me apoiou nessa jornada e que sempre acreditou em mim e no meu sucesso. Obrigada por continuar acreditando.

À minha psicóloga, Luisa, que me acompanhou desde o segundo ano da faculdade e me deu suporte todas as vezes que eu pensei em desistir. Obrigada por nunca ter desistido de mim e me mostrado caminhos que sozinha eu não teria visto. Foi graças a você que eu enfrentei, com muita coragem, os meus monstros e consegui realizar grandes projetos dentro da Universidade.

E falando em rede de apoio, não posso de deixar um agradecimento especial a professora Ana Sotero e a professora Andrea Cherman, que tiveram tanta empatia em períodos muito difíceis da minha vida. Obrigada por terem sido mais que professoras.

Aos meus amigos da PUC e da vida, por tornarem essa jornada recheada de lembranças boas e experiências incríveis. Obrigada pelos puxões de orelha, vocês me ensinaram muito e sem dúvida fazem parte da pessoa que sou hoje. Um agradecimento especial à Dudinha, que me acompanhou e me abrigou em sua casa. Obrigada pelas noites de estudo, comidinhas gostosas e idas na praia para distrair a cabeça, nossa parceria foi essencial! E à Mayra, obrigada por ser a pessoa que fez eu me sentir confortável para falar qualquer coisa e ter a certeza de que iria ser compreendida. Obrigada especialmente pelo apoio na reta final, seu suporte foi muito importante.

Aos amigos que fiz em minha trajetória profissional, em especial à Gi, que me ensinou muito sobre a vida e sobre liderança. Obrigada pela caminhada que tivemos juntas, foi um prazer enorme ter sido sua estagiária e poder te ter como amiga hoje em dia.

Ao meu orientador, Marcus Hemais, que me acompanhou e me ensinou muito no meu Pibic e agora com este trabalho. Obrigada pela paciência, empatia e carinho. Tudo se tornou mais leve sob sua orientação.

Por fim, agradeço a todos os professores e funcionários da PUC-Rio que fizeram parte da minha trajetória e me ensinaram tanto. 


\section{Resumo}

Dos Santos Prava, Brenda. O Marketing Interno como Ferramenta de Implementação e Gestão de um Programa de Diversidade. Estudo de caso do programa de diversidade da Ball Corporation. Rio de Janeiro, 2021. Número de páginas 78. Trabalho de Conclusão de Curso - Departamento de Administração. Pontifícia Universidade Católica do Rio de Janeiro.

Este estudo teve como objetivo analisar como o marketing interno foi utilizado na implementação e gestão do programa de diversidade da Ball Corporation. Para isso, foram realizadas entrevistas qualitativas, primeiro com a gerente de diversidade e inclusão da empresa, Suellen Moraes, e, na segunda etapa, com funcionários diversos da empresa. A metodologia utilizada foi a qualitativa e exploratória. Através dos dados coletados, foi possível entender o grau de utilização dos conceitos de marketing interno para a implementação do programa de diversidade e inclusão na empresa, entendendo de que forma esse olhar valoriza a percepção do programa.

Palavras-chave

Diversidade, Inclusão, Marketing Interno, Gestão, Motivação, Satisfação. 


\section{Abstract}

Dos Santos Prava, Brenda. The Internal Marketing as an Implementation and Management Tool to a Diversity Program. A Study Case of the Ball Corporation Diversity Program. Rio de Janeiro, 2021. Pages Number 78. Final Paper -- Administration Department. Pontifícia Universidade Católica do Rio de Janeiro.

This paper aims to analyse how internal marketing was employed in the implementation and management of the Ball Corporation Diversity Program. In the first stage, a qualitative interview was conducted with Suelen Moraes, Head of Diversity and Inclusion of the Company. The second part consisted of interviews with the company employees. Exploratory and qualitative methodology were applied. By mining the data collected, it was possible to realise the degree of use of internal marketing concepts in order to implement the Diversity and Inclusion Program, understanding how this point of view values the program perception.

Key-words:Diversity, Inclusion, Internal Marketing, Management, Motivation, Satisfaction. 


\section{Sumário}

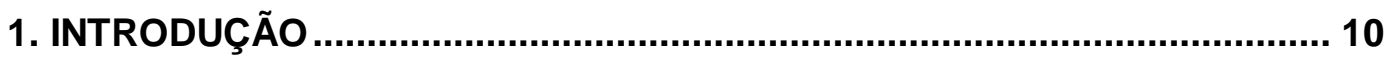

1.1. OBJETIVO DO ESTUDO ............................................................. 11

1.2. RELEVÂNCIA DO ESTUDO ...................................................... 11

1.3. DELIMITAÇÃO DO ESTUDO …................................................ 12

2. REFERENCIAL TEÓRICO........................................................................ 13

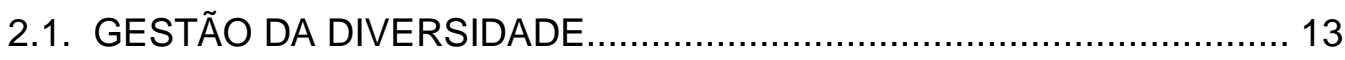

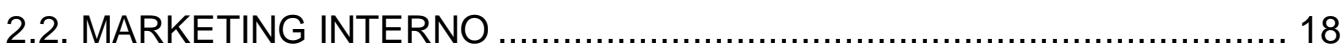

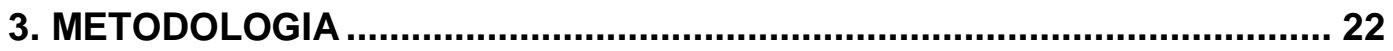

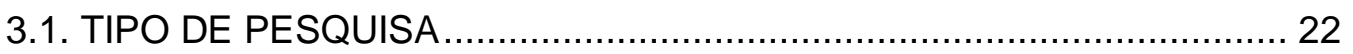

3.2 SELEÇÃO DOS ENTREVISTADOS …............................................. 22

3.3. COLETA DE DADOS E INFORMAÇÕES ........................................ 24

3.4. TRATAMENTO DE DADOS ....................................................... 24

3.5. LIMITAÇÕES DO MÉTODO ............................................................ 24

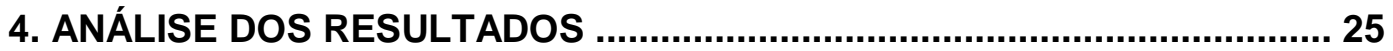

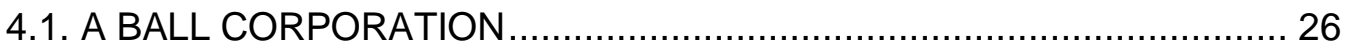

4.2. OPINIÃO SOBRE A ATUAÇÃO COM DIVERSIDADE NA BALL

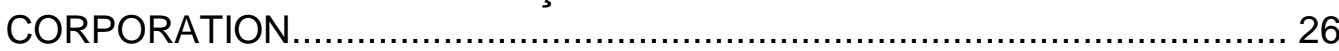

4.2.1. Implementação do programa de diversidade ................................ 26

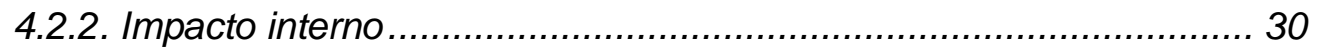

4.2.3. Impacto externo ................................................................ 32

4.3. PERCEPÇÃO DOS FUNCIONÁRIOS .................................................. 33

4.3.1. Percepção da importância de abordar o tema .............................. 33

4.3.2. Impacto no dia a dia ................................................................ 34

4.3.3. Percepção e conhecimento sobre o programa.............................. 36

4.4. RELAÇÃO ENTRE AS DUAS ETAPAS DA PESQUISA ........................ 38

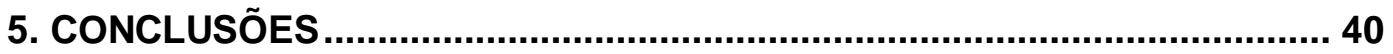


5.1. IMPLICAÇÕES GERENCIAIS ....................................................... 42

5.2. RECOMENDAÇÕES PARA NOVOS ESTUDOS ............................... 42

REFERÊNCIAS BIBLIOGRÁFICAS ....................................................... 44

APÊNDE 1: ROTEIRO DE ENTREVISTA COM O GRUPO 1 .......................... 47

APÊNDE 2: ROTEIRO DE ENTREVISTA DO GRUPO 2.............................. 49

APÊNDE 3: RESPOSTAS ENTREVISTA GRUPO 1 .................................. 51

APÊNDE 4: RESPOSTAS ENTREVISTAS GRUPO 2 ..................................56 


\section{Lista de Imagens}

Figura 1: Aspectos conceituais da diversidade ao longo do tempo.................... 14

Figura 2: Evolução da Sensibilidade Intercultural ...................................... 17 


\section{Lista de tabelas}

Tabela 1: Principais conceitos do Marketing Interno ...................................... 19

Tabela 2: Profissional que atua diretamente com o programa de diversidade da

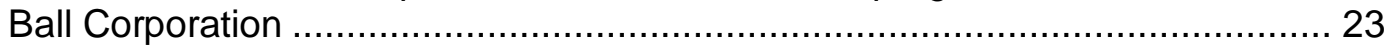

Tabela 3: Perfil dos entrevistados que trabalham em outras áreas da empresa 23 Tabela 4: Grau de utilização dos conceitos de marketing interno no programa de diversidade da Ball Corporation.................................................................... 39 


\section{Introdução}

As empresas estão cada vez mais preocupadas com a questão da diversidade entre os seus funcionários. Diversidade pode ser entendida no presente estudo como a reunião de tudo aquilo que apresenta múltiplos aspectos e que se diferenciam entre si, como, por exemplo: diversidade cultural, de gênero, étnica, linguística, religiosa etc. (SIGNIFICADOS, 2014). Refere-se às diversas identidades social e cultural entre pessoas que convivem no mesmo sistema e que influenciam significativamente suas experiências de vida (COX, 2001).

A preocupação em haver diversidade tem a ver com o fato de que, nos dias atuais, há pressões internas e externas para empresas adotarem tais ações em suas práticas; internamente, pelos seus próprios quadros de funcionários, e externamente pela sociedade (SAJI, 2005), que vem identificando um padrão excludente na contratação e promoção de pessoas, principalmente para cargos de liderança (ANTUNES et al., 2017).

Nesse sentido, a forma como o tema de diversidade tem se desenvolvido no meio empresarial é fruto do contexto no qual essa discussão está inserida, de constantes mudanças e de uma valorização e percepção das grandes diferenças dos indivíduos.

Com o objetivo de estar inseridas nesse cenário, as empresas buscam implementar programas de gestão da diversidade que se alinhem ao atual contexto demográfico da sociedade, desenvolvendo iniciativas internas que visam o combate ao preconceito e a redução da discriminação. Um exemplo é o caso da Magazine Luiza, uma empresa familiar da área de varejo, que recentemente abriu seu processo seletivo de trainees apenas para pessoas negras. A estratégia adotada pela empresa, segundo o presidente Frederico Trajano, "buscar reverter o número de funcionários e o de lideranças negras dentro da companhia". Além de a decisão refletir a realidade da população brasileira, aumentando as vendas e gera maior valor ao acionista (Seu dinheiro, 2020).

O motivo para adoção de tais programas não é, entretanto, somente por causa das diferentes pressões. A diversidade dentro das empresas ajuda a potencializar vantagens competitivas, pois as diferenças individuais podem gerar diferenças agregadoras, trazendo novas perspectivas para as estratégias 
organizacionais. Além disso, a gestão da diversidade nas organizações tem uma influência positiva no ambiente de trabalho, melhorando, consequentemente, a imagem da empresa (SICHEROLLI; MEDEIROS; JÚNIOR; 2011, p. 1).

Nos Estados Unidos e na Europa, independente das perspectivas de diversidade adotadas, o perfil de funcionários das organizações vem se diversificando cada vez mais nas últimas décadas. No Brasil, essa é uma questão mais complexa, visto seu contexto histórico e sociocultural, considerando a ideologia da democracia racial brasileira, que mascara o preconceito e entra em conflito com a ideologia da gestão da diversidade (ALVES; GALEÃO-SILVA; 2004, p. 21). O Brasil é caracterizado por ser uma sociedade heterogênea, em termos sociais, étnicos, econômicos, culturais e educacionais, sendo estas, características que, teoricamente, agregam valor ao país.

Nesse sentido, a implementação de um programa de diversidade nas organizações brasileiras geralmente precisa de ferramentas que fomentem o engajamento dos funcionários e a aceitação dos tomadores de decisão. O marketing interno, portanto, pode ser um facilitador na implementação e na gestão dos programas de diversidade das empresas, pois ele tem como principal objetivo o engajamento e a satisfação do público interno.

O marketing interno é uma ferramenta de estratégia de fidelização e envolvimento dos colaboradores, a fim de desenvolver uma cultura organizacional voltada para o cliente interno e externo, por meio da qual os colaboradores representem o primeiro mercado para as organizações (FERNANDES; FERREIRA, LEBARCKY; 2011).

É dentro desse contexto que o presente estudo pretende analisar como o marketing interno pode ajudar na implementação e na gestão de um programa de diversidade em uma empresa.

\subsection{Objetivo do Estudo}

Diante desse cenário, o presente trabalho tem como objetivo analisar como o marketing interno é utilizado para implementação e gestão do programa de diversidade da Ball Corporation.

\subsection{Relevância do estudo}

Conforme apontado na introdução, no Brasil, a prática da diversidade pode ser um desafio para as empresas, visto seu contexto diverso e com um histórico 
excludente de pessoas socialmente discriminadas no mercado de trabalho (SAJI, 2005). Com isso, a gestão de um programa de diversidade pode se tornar um desafio para as empresas brasileiras. O presente estudo, portanto, busca analisar, na prática, como o marketing interno pode ser uma ferramenta em potencial para a gestão e implementação de um programa de diversidade de uma grande empresa. O conhecimento gerado pode, então, servir como guia para outras empresas que queiram seguir tal caminho ou a ajudar as organizações a melhorarem seus programas de diversidade através da observação do marketing interno como ferramenta de implementação e gestão de um programa bem estruturado.

Pela ótica acadêmica, Silva (2012) analisa a cultura organizacional e o desempenho empresarial do Magazine Luiza, que se destaca por ser uma organização com práticas de gestão flexíveis e participativas. Entretanto, não há estudos que relacionem esse perfil de empresa com um programa de gestão da diversidade bem estruturadas com o marketing interno. O presente estudo pretende, portanto, trazer mais conhecimento sobre o tema e ajudar a trazer luz a essa lacuna na literatura.

\subsection{Delimitação do estudo}

Nesse estudo, será analisado o marketing interno, através de alguns de seus principais aspectos, como resolução de conflitos, engajamento do funcionário, apoio a liderança, orientação para o mercado, recrutamento e seleção e comunicação interna.

Além disso, delimita-se o estudo a analisar o programa de diversidade da Ball Corporation, do ponto de vista interno da empresa, não levando em consideração os resultados financeiros ou a visão dos stakeholders.

A Ball Corporation é uma empresa multinacional americana, que fabrica latas de alumínio para bebidas, embalagem de aerossol no mercado da beleza e atua no setor aeroespacial, fabricando peças para satélites. 


\section{Referencial Teórico}

O presente capítulo discute o referencial teórico do estudo. Está dividido em dois temas, sendo eles, primeiramente sobre a gestão da diversidade e, posteriormente, sobre o Marketing Interno.

\subsection{Gestão da diversidade}

O tema da diversidade já faz parte dos estudos da Antropologia há mais de 150 anos (Presotti, 2011), entretanto, na literatura de gestão, o assunto só começou a ser abordado nas últimas três décadas (Jonsen; Maznevski; Schneider, 2011). Pode se entender por diversidade a representação de pessoas com diferentes identidades grupais em um sistema social (COX, 1994), ou seja, diversidade está diretamente ligada à união de pessoas diferentes e com características únicas que formam sua identidade.

A diversidade exerce impacto direto nas relações de trabalho e começou a ser estudada nesse ambiente a partir dos anos 1950, por conta da Declaração Universal dos Direitos Humanos da Organização das Nações Unidas (1948). Desde então, o tema vem sendo considerado elemento de grande importância para a formação da força de trabalho (COOKE, 1999) e o conceito evoluiu historicamente, como pode-se observar na Figura 1, a seguir: 
Figura 1: Aspectos conceituais da diversidade ao longo do tempo

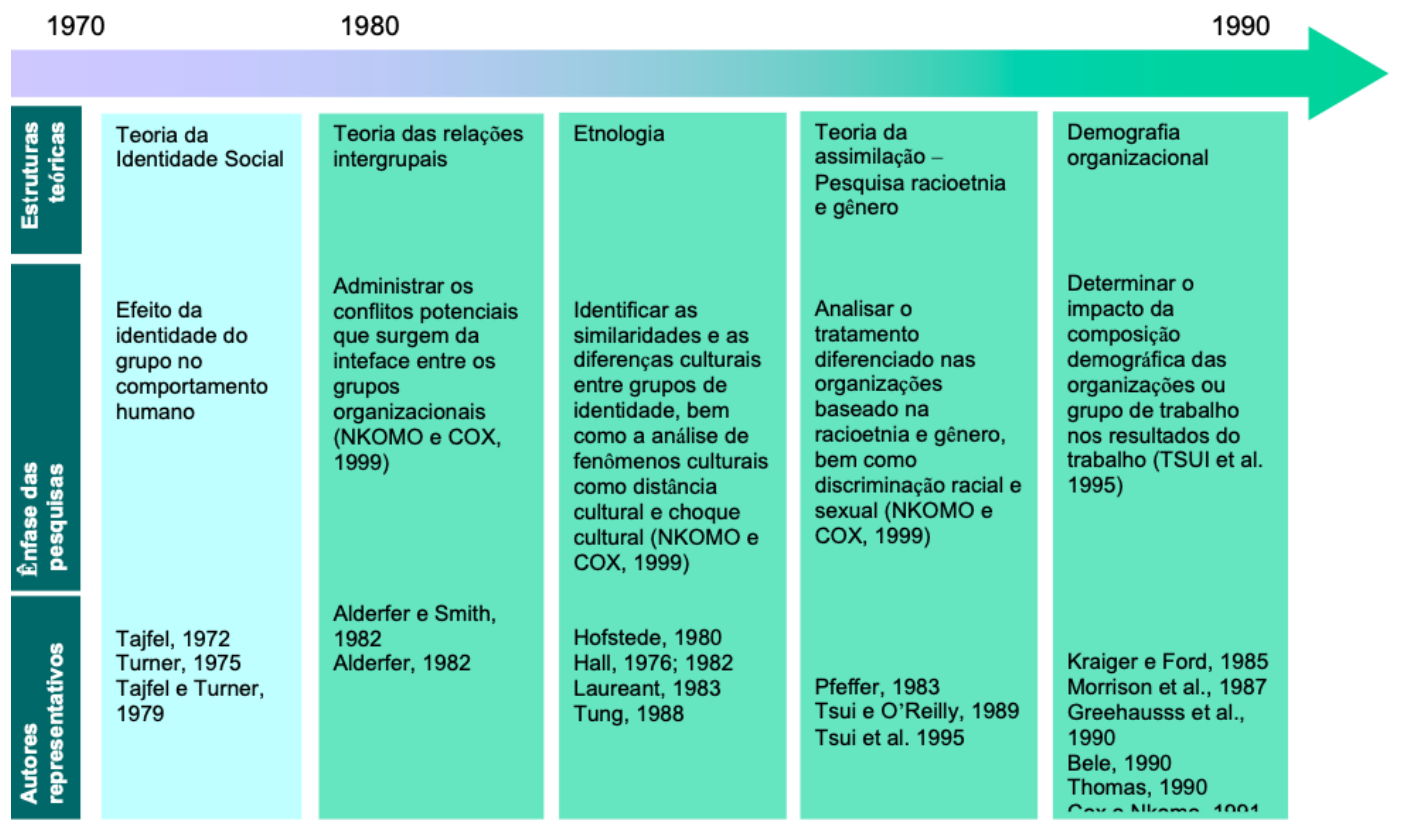

Fonte: Dos Santos; Rodrigues; Costa, 2008

A gestão da diversidade surgiu, então, na década de 1990 com programas de diversidade e políticas proativas que têm como objetivo desenvolver uma força de trabalho mais diversa e mais esclarecida quanto às diferenças existentes em diversos grupos sociais (MOR BARAK, 2011).

O gerenciamento da diversidade, segundo Torres e Pérez-Nebra (2004, p.444), se trata do "desenvolvimento e do estabelecimento de normas organizacionais que valorizam as diferenças entre os grupos para a melhoria da efetividade organizacional e não que promovam essa efetividade apesar das diferenças". Os grupos podem ser entendidos como a união de pessoas com características que se diferenciam entre si, como etnia, idade, gênero, orientação sexual etc.

Nesse sentido, a gestão da diversidade surge como resposta do mercado dos EUA às políticas de ação afirmativa das décadas de 1960 e 1970. Vale ressaltar que as ações afirmativas surgiram através de intervenção política, com o objetivo de tentar reverter desigualdades em determinadas sociedades, enquanto a gestão da diversidade é uma ação prática adotada pelas organizações, que visa o enfrentamento das desigualdades através de uma ótica meritocrática, desenvolvendo economicamente os indivíduos e as empresas (ALVES; GALEÃO-SILVA, 2004).

No Brasil, entretanto, existem elementos, como a ideologia da democracia racial, que dificultam o desenvolvimento de programas de diversidade, pois entra 
em tensão com a ideologia da gestão da diversidade (ALVES; GALEÃO-SILVA, 2004). Esse contexto nacional diversificado e contraditório faz com que as empresas nacionais não percebam os benefícios concretos que a diversidade pode trazer para a organização e seus funcionários.

O reconhecimento da discriminação de negros no mercado de trabalho, por exemplo, só ocorreu no Brasil recentemente (em 1990) através de lutas dos movimentos sociais por políticas de ação afirmativa (SOARES, 2000). Fatores como estes, que são característicos da construção histórica do país, dificultam a gestão de uma implementação bem estruturada de um programa de diversidade, trazendo resultados negativos por falta de um bom gerenciamento.

Nesse sentido, a efetividade de um programa de diversidade deve vir da mudança de padrões culturais dominantes em uma organização e da identificação de políticas e práticas que devem ser implementadas para essa mudança (Fleury, 2000).

O sistema de gestão deve focar na redução de conflitos e mitigação da discriminação, considerando e valorizando as particularidades que vão além das vantagens e desafios de um ambiente de trabalho diversificado (FERNANDES; FERREIRA; LEBARCKY, 2011). A implementação de um programa de diversidade ajuda a estabelecer um plano de ação que acompanhe essa gestão.

A gestão da diversidade tem como objetivo uma transformação sistêmica da organização, ou seja, abrange a organização como um todo e não apenas passa pelos sistemas de recrutamento e seleção (TORRES; PÉREZ-NEBRA, 2004), o que possibilite criar um ambiente organizacional onde todos possam desenvolver plenamente seu potencial na realização dos objetivos da empresa (Thomas, 1996). Para haver uma gestão de implementação de um programa de diversidade, é necessário um plano de ação, visto que ela não se restringe a um pacote com soluções prontas.

Conforme citado por Pessanha (2020), em seu trabalho de conclusão de curso de graduação, Marie-Josée Lorrain, Ph.D. na Universidade du Québéc à Montréal (UQÀM), propôs um plano de equidade e diversidade no trabalho contendo dois pilares, dividido em 12 partes, com o objetivo de elaborar uma boa gestão de implementação de um programa de diversidade. O primeiro pilar consiste em realizar, primeiramente, um diagnóstico quantitativo interno, a fim de determinar a taxa de representatividade de cada grupo alvo (gênero e etnia, por exemplo) em cada cargo da empresa. A partir disso, deve-se analisar as taxas de representatividade dos grupos alvos na população em que a empresa está inserida. Isso possibilita entender de forma mais clara as diferenças existentes em 
cada organização, partindo de seu contexto. O segundo pilar busca determinar os objetivos e as ações corretivas a partir do diagnóstico realizado anteriormente. Deve-se determinar a representatividade de cada grupo alvo que a empresa busca ter, o que já deve estar previsto em um cronograma estruturado e completo, que contenham informações referentes ao plano de ação desejado pela empresa, como, por exemplo, previsão de contratação, taxa de rotatividade, promoção etc. No âmbito qualitativo, o segundo pilar deve passar por três etapas:

- Ajuste: o objetivo é aumentar a representatividade dos grupos alvos nos cargos em que a empresa identificou sub-representatividade.

- Igualdade de oportunidades: visa corrigir práticas e políticas discriminatórias, seja de forma direta ou indireta

- Apoio: visa ajudar no alcance dos objetivos, tornando o local de trabalho acolhedor

As 12 etapas que fazem parte dos pilares explicados acima são as seguintes:

1. Reunir os atores envolvidos na equidade no trabalho (membros da direção de Recursos Humanos; membros do sindicato; a pessoa inicialmente responsável pela implementação do plano de equidade);

2. Desenhar o perfil dos funcionários de cada serviço de acordo com etnia, gênero e outras categorias;

3. Identificar os grupos sub-representações por cargos, funções e direção;

4. Avaliar a possibilidade de substituição desses cargos;

5. Estabelecer necessidades de substituição da força de trabalho para cada cargo em cada departamento (a curto e longo prazo);

6. Definir os objetivos e meios de diversificar a força de trabalho por grupo-alvo;

7. Identificar todos os obstáculos do recrutamento;

8. Criar oportunidades para atrair, treinar e recrutar essa força de trabalho procurada;

9. Programar todos os objetivos e recursos em uma tabela dividida em períodos;

10. Avaliar o atingimento dos objetivos;

11. Identificar quais estratégias foram positivas e trouxeram resultado e quais devem ser revisadas;

12. Rever e ajustar os objetivos em função dos resultados obtidos. 
Esse plano faz parte de uma das etapas da implementação de um programa de diversidade, pois passa por todo sistema de contratação, no qual apenas o $\mathrm{RH}$ é responsável. As ações cotidianas que promovem um ambiente mais acolhedor e sensível em relação à diversidade perpassa por vários outros sistemas e processos organizacionais de uma empresa, o que facilita a integração das pessoas, considerando todas as visões culturais, não apenas dos grupos considerados dominantes.

Por conta disso, faz-se necessário um plano que vai além da contratação, mas que envolva políticas de desenvolvimento de habilidades que facilitem 0 relacionamento dos funcionários com pessoas de outras culturas, ou seja, o desenvolvimento de uma competência de comunicação intercultural, que significa desenvolver a capacidade do indivíduo de dialogar com pessoas de outra origem cultural, com respeito à sua cultura, os seus valores e as suas experiências (IRIPI, 2017).

Segundo Maccali et al (2015) práticas bem estruturadas de recursos humanos nos projetos de inclusão para a gestão da diversidade são fundamentais para a eficácia da inclusão. Entretanto, é essencial políticas de manutenção desse programa, com investimento contínuo na gestão da diversidade.

O modelo de Desenvolvimento de Sensibilidade Intercultural, proposto por Bennett (2004), conta com seis fases, divididas em etnocêntricas e etnorelativas, ilustradas na Figura 2 a seguir:

Figura 2: Evolução da Sensibilidade Intercultural

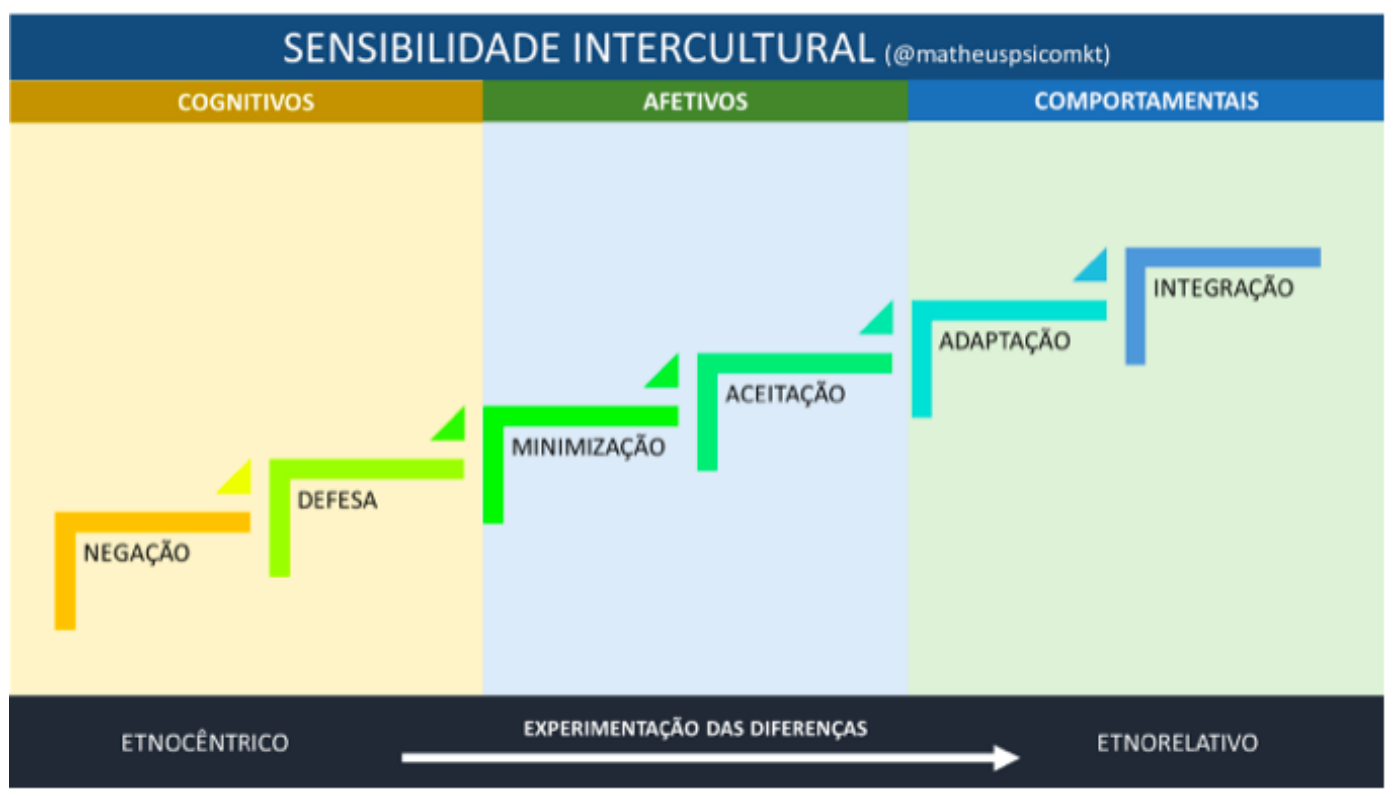

Fonte: Bennett, 2004 
O objetivo é que os indivíduos cheguem na fase de integração, mesmo que ele se encontre em outra fase ao mesmo tempo. Nesta fase, já foi desenvolvido um senso de si mesmo como pertencente a outras culturas ou grupos e está confortável com a relatividade cultural (AFS Intercultural Programas, 2012).

Para avançar em cada fase, Bennett e Bennett (2004) identificaram tarefas chave para os indivíduos que se encontram em cada uma dessas etapas:

- Na etapa de negação os indivíduos devem entender e reconhecer a existência de diferenças culturais;

- Na etapa de Defesa, indivíduos podem diminuir uma perspectiva polarizada, trazendo o sentimento de "humanidade comum" e necessidades similares;

- Na etapa de Minimização, é importante o desenvolvimento de uma autoconsciência cultural e aprender que mesmo que haja similaridade entre as culturas, também há muitas diferenças;

- Na etapa de Aceitação, os indivíduos precisam melhorar suas análises dos contrastes culturais, colocando as diferenças culturais em foco e praticando a mudança de referência cultural;

- Na etapa de Adaptação, o indivíduo precisa aperfeiçoar sua habilidade com a referência cultural e aumentar seu grau de empatia com o outro.

O desenvolvimento da sensibilidade intercultural precisa fazer parte da gestão da diversidade, trazendo conforto para os funcionários em relação à relatividade cultural com o público interno e externo à organização.

\subsection{Marketing Interno}

O conceito de Marketing interno surgiu voltado para a satisfação das necessidades do empregado, visando uma melhor entrega para o cliente externo (HEMAIS; OLIVEIRA; CASOTTI; 2013). O marketing interno é, portanto, uma estratégia de gestão que visa desenvolver nos empregados uma consciência do cliente, além de integrar funcionários através da implementação eficaz de estratégias corporativas (RAFIQ; AHMED, 2000). Com isso, serão analisados aspectos que possibilitam a utilização do marketing interno como uma ferramenta para a implementação e gestão de um programa de diversidade em empresas, como a motivação de funcionários, o apoio da liderança, a coordenação interfuncional e integrada, a orientação para o mercado, o olhar para o funcionário 
como cliente interno, o treinamento, o recrutamento e seleção e a comunicação interna.

A Tabela 1, apresentada a seguir, traz os principais conceitos de Marketing Interno:

Tabela 1: Principais conceitos do Marketing Interno

\begin{tabular}{|c|c|}
\hline Conceito & Justificativa \\
\hline Marketing interno & $\begin{array}{l}\text { Não há uma definição única ou consensual } \\
\text { sobre o que é marketing interno, o que dever } \\
\text { ser feito, como fazer e quem deve fazê-lo. }\end{array}$ \\
\hline Satisfação e motivação & $\begin{array}{l}\text { Uma das principais funções do marketing } \\
\text { interno é satisfazer e motivar empregados, para } \\
\text { que isso se reflita nos resultados da empresa. }\end{array}$ \\
\hline $\begin{array}{l}\text { Orientação de mercado e satisfação do } \\
\text { cliente }\end{array}$ & $\begin{array}{l}\text { O marketing interno deve estimular a orientação } \\
\text { de mercado nos empregados, de forma que } \\
\text { todos trabalhem em prol da satisfação do cliente } \\
\text { externo. }\end{array}$ \\
\hline Coordenação interfuncional e integrada & $\begin{array}{l}\text { O marketing interno não deve ser tratado como } \\
\text { uma função especializada e deve ser } \\
\text { gerenciado por uma coordenação interfuncional } \\
\text { e integrada. }\end{array}$ \\
\hline Comunicação Interna & $\begin{array}{l}\text { A comunicação interna busca reforçar a } \\
\text { orientação para o mercado e estimular } \\
\text { determinados comportamentos por parte dos } \\
\text { empregados, partindo do pressuposto que estes } \\
\text { também têm necessidades que precisam ser } \\
\text { satisfeitas. }\end{array}$ \\
\hline Treinamento & $\begin{array}{l}\text { Dentro de um contexto de marketing interno, o } \\
\text { treinamento deve oferecer aos funcionários uma } \\
\text { visão de mercado, um foco no cliente. }\end{array}$ \\
\hline Recrutamento e seleção & $\begin{array}{l}\text { Dentro de um contexto de marketing interno, a } \\
\text { área de recrutamento e seleção deve buscar } \\
\text { candidatos que melhor possam atender às } \\
\text { expectativas do cliente. }\end{array}$ \\
\hline $\begin{array}{l}\text { Avaliação de desempenho e } \\
\text { recompensas }\end{array}$ & $\begin{array}{l}\text { A avaliação de desempenho deve medir a } \\
\text { contribuição do empregado para a estratégia da } \\
\text { empresa; as recompensas devem ser dadas } \\
\text { aos desempenhos que levam à direção }\end{array}$ \\
\hline
\end{tabular}


pretendida pela empresa e devem ser utilizados métodos diversificados de recompensa.

Fonte: Hemais, Oliveira e Casotti (2013)

O primeiro conceito explica o Marketing Interno, já abordado anteriormente. O segundo conceito é o de satisfação e motivação, que, de acordo com Berry e Parasuraman (1995), a principal preocupação do Marketing Interno deveria ser a satisfação e motivação do empregado, englobando seu desenvolvimento e valorização. A satisfação se refere ao sentimento de atingir qualquer meta ou objetivo (LOFQUIST; DAVIS, 1991) e a insatisfação, consequentemente, leva à falta de motivação no trabalho.

A motivação pode ser definida como a disposição do funcionário de se esforçar para alcançar as metas da organização. Atrelado esse esforço, está a satisfação de alguma necessidade individual (ROBBINS, 2000).

Sobre a orientação de mercado e a satisfação do cliente, Narver e Slater (1990) conceituam orientação de mercado através de 5 elementos, divididos em 3 componentes comportamentais (orientação para o cliente, orientação para o concorrente e coordenação interfuncional) e dois componentes de decisão (foco no longo prazo e rentabilidade). Este conceito está diretamente ligado à satisfação do cliente no Marketing Interno, pois é essa atividade que complementa a gestão de pessoas, no sentido de desenvolver uma orientação para o mercado em todos os funcionários, resultando no interesse dos empregados por clientes e marketing (GRÖNROOS, 1995).

A coordenação interfuncional e integrada tem por objetivo integrar funções internas, trazendo benefícios para a empresa, como a melhoria do desempenho da organização como um todo e em seus departamentos, e a redução de conflitos, promovendo assim um suporte mais amplo na tomada de decisão e planejamento (PIMENTA; DA SILVA; 2010).

A comunicação interna é responsável pela efetividade da comunicação entre os funcionários de uma empresa (CARDOSO, 2005). Segundo Hemais, Oliveira e Casotti (2013, p.112), "a comunicação interna busca reforçar a orientação para o mercado e estimular determinados comportamentos por parte dos empregados, partindo do pressuposto de que estes também têm necessidades que precisam ser satisfeitas."

O treinamento, segundo Cascio (1995) apoia o desenvolvimento de capacidades dos indivíduos que estabelecem vantagem competitiva sustentável à 
organização. Ou seja, ele capacita os colaboradores de acordo com as funções exercidas do seu cargo, visando produtividade e motivação do funcionário.

No marketing interno, o treinamento deve proporcionar aos funcionários uma visão de mercado com foco no cliente (HEMAIS; OLIVEIRA; CASOTTI; 2013), ou seja, o treinamento deve orientar o funcionário a realizar suas funções da melhor maneira possível e com um olhar externo, ampliando seu modo de trabalhar para além das funções exercidas.

O recrutamento é o processo de buscar no mercado pessoas com características alinhadas à cultura da empresa e com as demandas das áreas solicitantes. A seleção é o processo complementar do recrutamento, onde é feita a escolha dos candidatos que se enquadram com o perfil da vaga (GUIMARÃES; ARIEIRA, 2005). A área de Recrutamento e Seleção que deseja estar alinhada aos conceitos de marketing interno deve levar em consideração características dos perfis que melhor atendam os clientes externos (HEMAIS; OLIVEIRA; CASOTTI; 2013).

Os últimos conceitos discutidos são os de avaliação de desempenho e recompensas, que medem a contribuição do funcionário para o alcance de metas atreladas à estratégia da empresa, além dos métodos de recompensa e bonificação utilizados para incentivar o alcance das metas (HEMAIS; OLIVEIRA; CASOTTI, 2013).

Esses conceitos, juntos, formam as principais atividades de um programa bem-sucedido de marketing interno, portanto, para a implementação da gestão da diversidade através do marketing interno, essas etapas são essenciais para o alcance de um programa de diversidade bem estruturado. 


\section{Metodologia}

O presente capítulo apresenta a metodologia adotada no estudo e está dividido em cinco tópicos. $O$ primeiro refere-se ao tipo de pesquisa realizado. $O$ segundo descreve a seleção dos entrevistados para a pesquisa. O terceiro destaca como os dados foram coletados, sendo subdividido em dois subtópicos, referentes às duas etapas da coleta de dados. O quarto tópico aborda o tratamento dos dados coletados. Por fim, o quinto tópico traz as limitações do método adotado na pesquisa.

\subsection{Tipo de pesquisa}

O tipo de pesquisa realizado no presente estudo será o exploratório, levando em consideração que o tema apresentado foi pouco explorado, e por conta disso há poucas experiências e informações a seu respeito. Gil (2007) define a pesquisa exploratória como uma procura por maior familiaridade com o problema, a fim de torná-lo explícito, auxiliando na construção de hipóteses.

Além de exploratória, a pesquisa também adota a abordagem qualitativa, que, segundo Zikmund (2005), apresenta uma natureza subjetiva, na qual a avaliação do pesquisador forma os resultados, sem a necessidade de análises estatísticas.

\subsection{Seleção dos entrevistados}

Neste estudo, as entrevistas foram realizadas duas etapas de entrevistas dentro da Ball Corporation. A primeira etapa foi realizada com a profissional que atua diretamente com o programa de diversidade da empresa. O objetivo de entrevistar essa profissional foi o de analisar a forma que o programa de diversidade foi implementado e como é feita a gestão e manutenção desse programa, os desafios envolvidos nessa gestão, os impactos nos funcionários e de que forma o marketing interno esteve presente nesse processo. A segunda etapa consistiu de entrevistas com funcionários de diferentes áreas da empresa, buscando entender o impacto e a percepção do programa para eles. Nesse grupo 
de funcionários, foram incluídos os contratados e os promovidos como parte das diretrizes do programa de diversidade da empresa, a fim de verificar a coerência do programa e de que forma afeta a dinâmica de trabalho dessas pessoas em função dos conceitos de marketing interno e gestão da diversidade.

A seleção da entrevistada do primeiro grupo foi feita através da indicação do diretor estratégico de $\mathrm{RH}$ da empresa e foi realizada com a gerente geral da área de diversidade e inclusão da América do Sul.

A seguir, encontra-se a Tabela 1, na qual constam as informações da entrevistada na primeira etapa da pesquisa.

Tabela 2: Profissional que atua diretamente com o programa de diversidade da Ball Corporation

\begin{tabular}{|l|l|l|l|}
\hline ENTREVISTADA & \multicolumn{1}{|c|}{ CARGO } & TEMPO NA EMPRESA & $\begin{array}{c}\text { TEMPO DE ATUAÇÃO } \\
\text { COM DIVERSIDADE }\end{array}$ \\
\hline Suellen & $\begin{array}{l}\text { Gerente de Diversidade e } \\
\text { Inclusão na América do Sul }\end{array}$ & 10 anos & 10 anos \\
\hline
\end{tabular}

Fonte: Elaborado pela autora

O segundo grupo de entrevistados foi selecionado através da indicação da gerente de $\mathrm{RH}$ seguindo o critério de pertencerem a áreas distintas da empresa. Apesar de não ter havido nenhuma restrição para a seleção, foram entrevistados 3 homens e 4 mulheres. A idade média dos respondentes é de 27,4 anos.

A seguir, a Tabela 2 descreve o perfil desses entrevistados.

Tabela 3: Perfil dos entrevistados que trabalham em outras áreas da empresa

\begin{tabular}{|l|l|l|l|l|}
\hline ENTREVISTADO & \multicolumn{1}{|c|}{ GÊNERO } & \multicolumn{1}{|c|}{ IDADE } & \multicolumn{1}{|c|}{ CARGO } & TEMPO NA EMPRESA \\
\hline Mariany & Feminino & 22 & Técnica de manutenção eletrônica & 7 meses \\
\hline Quezia & Feminino & 24 & Assistente de RH & 2 anos e 6 meses \\
\hline Saulo & Masculino & 30 & Analista de TI & 4 anos \\
\hline Amanda & Feminino & 26 & Estagiária de melhoria contínua & 7 meses \\
\hline Vandson & Masculino & 38 & Analista de planejamento de manutenção & 19 anos \\
\hline Raphael & Masculino & 28 & Assistente de logística & 2 anos e 6 meses \\
\hline Nathalia & Feminino & 24 & $\begin{array}{l}\text { Estagiária de meio ambiente e segurança } \\
\text { do trabalho }\end{array}$ & 6 meses \\
\hline
\end{tabular}

Fonte: Elaborado pela autora 


\subsection{Coleta de dados e informações}

A coleta de dados foi realizada através de entrevistas em profundidade. As entrevistas foram realizadas via zoom/google meet, com autorização prévia dos entrevistados para que as conversas fossem gravadas e, posteriormente, transcritas.

Para guiar as entrevistas, foram elaborados dois roteiros (disponíveis no Apênde 1 e 2). O primeiro roteiro, que pautou a entrevista com a gerente da empresa, contém 14 questões baseadas no referencial teórico, que buscavam analisar a relação do programa de diversidade da empresa com o marketing interno, a forma que esse programa foi implementado, o impacto que teve nos funcionários e como é feita a gestão e manutenção das práticas de diversidade na organização.

Para os funcionários, o roteiro utilizado continha 17 questões, todas também baseadas no referencial teórico, buscando entender de que forma 0 programa de diversidade afeta o trabalho dessas pessoas, suas vivencias na organização e a percepção sobre a empresa e o programa de diversidade.

\subsection{Tratamento de dados}

Após a coleta de dados, as entrevistas foram consolidadas e transcritas e as respostas organizadas em uma tabela para a visualização dos dados. Dessa forma, foi possível realizar uma análise completa e comparativa, a fim de identificar semelhanças e diferenças nas respostas dos grupos, destacando os pontos mais importantes e os relacionados com o referencial teórico.

\subsection{Limitações do método}

Todos os métodos de pesquisa podem apresentar limitações. Luna (2002) aponta os relatos verbais como fontes controversas de informação, pois tendem a ser um correlato de algum fenômeno. Para isso, é necessário que haja uma teoria que faça ponte com o relato para evitar assim uma análise tendenciosa dos dados.

Além disso, a disposição e o engajamento dos entrevistados na pesquisa também podem afetar os resultados. Fatores, como medo de expor uma opinião, falta de compreensão do que está sendo perguntado e o nível de conhecimento sobre o tema abordado, influenciam suas respostas e consequentemente a análise dos dados. 


\section{Análise dos resultados}

O presente capítulo apresenta a análise dos dados coletados, e está divido em quatro tópicos. No primeiro, apresenta-se a empresa, no segundo são analisadas as respostas obtidas com a entrevistada da etapa um. No segundo, as respostas dos entrevistados do grupo dois são analisadas. Por fim, no terceiro, é discutida a relação entre as respostas dos dois grupos.

\subsection{A Ball Corporation}

A Ball Corporation é uma multinacional americana, fundada em 1880, que fabrica latas de alumínio para bebidas. A empresa iniciou sua produção como fabricante de latas com revestimento de madeira, para produtos como tinta e querosene, se expandindo para embalagens de vidro e estanho. Ela possui três segmentos: de embalagem de alumínio para bebidas, embalagem para aerossol no mercado de beleza e a área de aerospace, fabricando peças para satélite, a fim de atender o governo americano e outras instituições desse segmento, como a NASA.

A empresa é líder mundial na área, com mais de 20 mil funcionários ao redor do mundo e possui 14 fábricas na América Latina, sendo 11 no Brasil, uma no Chile, uma na Argentina e uma no Paraguai.

A sustentabilidade é uma mensagem forte e consolidada na empresa, tanto interna como externamente. Seu processo de reciclagem é forte, com $97 \%$ das latas de alumínio voltando para as fábricas em 60 dias. O CEO, John Hayes, colocou a diversidade no mesmo patamar que a sustentabilidade, fazendo D\&I (Diversidade e Inclusão) uma causa pessoal e trazendo o reporte da área diretamente para si, por identificar que faltavam ações concretas sobre o tema dentro da empresa.

Seu programa de diversidade começou com a estruturação da área de D\&I em 2015, exclusivamente nos EUA com um trio de treinamento global: o Thinking Inclusively, que pensa na forma de se endereçar vieses inconscientes; o Speak Inclusively, que é a fala de forma inclusiva e o Meet Inclusively, que diz respeito à 
transformação dos encontros em encontros inclusivos, que façam as pessoas se sentirem confortáveis para dar suas opiniões sem medo de serem tolhidas.

Com a evolução dos treinamentos voltados à diversidade e inclusão, a área estruturou grupos de afinidade, conhecidos como os BRG's (Ball Ressource Group) e hoje, existem mais de 20 grupos de afinidade e de interesse, que são grupos de pessoas que se reúnem com uma paixão em comum, como fotografia, ciclismo etc. Os EUA, por exemplo, têm grupos de veteranos, mulheres e o pride network.

Em 2020, a área foi instaurada em todas as regiões de operação da empresa, de modo que cada uma ficou responsável por estruturar a área de D\&I em suas respectivas regiões.

A empresa já recebeu o selo Forbes de melhor empresa para se trabalhar para o público LGBTQIA+, nos EUA.

\subsection{Opinião sobre a atuação com diversidade na Ball Corporation}

O objetivo da entrevista direcionada a primeira etapa do estudo foi o de entender de que forma o programa de diversidade foi implementado, os principais desafios, quais os impactos nos funcionários e de que forma o marketing interno esteve presente nesse processo. A análise desses resultados será dividida em três partes: a implementação do programa, o impacto interno e o impacto externo.

\subsubsection{Implementação do programa de diversidade}

Um dos passos mais importantes para implementar um programa de diversidade é entender qual é a motivação da empresa para isso, de onde surgiu a ideia e onde a empresa quer chegar com as suas ações. Dessa forma, ela se mantém alinhado com a sua realidade e com seus objetivos (JÈZÈQUEL, 2008).

O programa de diversidade da Ball foi implementado recentemente, no ano de 2021, e ainda está em processo de estruturação. Em entrevista com os entrevistados do grupo 1, notou-se que as principais motivações para se fazer um trabalho de sensibilização sobre diversidade e inclusão foram de demandas externas e internas. É possível observar isso no seguinte depoimento:

A empresa buscava que as pessoas se sentissem confortáveis, porque, segundo uma pesquisa da Mackenzie, quando a pessoa precisa se esconder, 
ele vai gastar $30 \%$ da energia dele escondendo quem ele é. Então, além de ser o certo a se fazer, estamos falando de organizações, e elas precisam ser eficientes e inovadoras. Quando se investe em diversidade, empresas com diversidade de gênero, por exemplo, lucram mais do que empresas que não possuem diversidade de gênero. Diversidade também ajuda no engajamento dos funcionários, fazendo com que o nível de retenção seja maior, no posicionamento da empresa frente ao mercado, além de possibilitar a compreensão das expectativas do cliente, antecipando tendências de consumo, sem o risco do pensamento único. (Suellen)

Além disso, a empresa percebeu que o quadro de funcionários da fábrica era majoritariamente masculino, tornando desproporcional o número de homens e de mulheres entre os funcionários. Suellen explica que "A Ball é uma indústria e, apesar de ter um processo produtivo automatizado, ela é predominantemente masculina, com uma média de $10 \%$ de mulheres nas fábricas."

É interessante frisar que uma gestão ativa da diversidade, que atinja diferentes identidades, traz vantagem competitiva para as organizações, diferentemente de ações afirmativas que carregam uma pressão coercitiva externa de responsabilidade social (ALVES; GALEÃO-SILVA, 2004). Além de que essa gestão tem um impacto na motivação e satisfação dos colaboradores.

O marketing interno tem como um de seus principais objetivos satisfazer e motivar empregados, de forma a refletir nos resultados da empresa (HEMAIS; OLIVEIRA; CASOTTI; 2013) e de fato, estudos mostram que a diversidade nas empresas tende a promover criatividade e, consequentemente, a inovação (THOMAS E ELY, 2001). Pode-se ver no relato de Suellen que a visão da empresa está alinhada a isso: "Empresas diversas são muito mais criativas e inovadoras, pois proporciona segurança psicológica às pessoas, fazendo com que suas ideias sejam expostas sem medo."

Com isso, observa-se que um dos objetivos com a implementação do programa de diversidade na Ball Corporation é criar um ambiente seguro, onde as pessoas se sintam confortáveis em expor suas ideias, gerando um ambiente mais inovador. 
Depois de entender o que motivou a empresa, buscou-se analisar os principais desafios no momento da implementação do programa.

A Ball é uma empresa multinacional com sede nos Estados Unidos, onde a agenda de diversidade e inclusão é mais avançada. No Brasil, o tema ainda é novo e, segundo a entrevistada, menos de $20 \%$ das empresas no país têm metas atreladas à diversidade. Então, uma das dificuldades foi achar referências no mercado. Outro desafio foi a mudança de cultura, que envolve educar e sensibilizar a população interna da empresa e isso leva tempo e demanda vários esforços. A entrevistada também relatou que um grande desafio é a restrição de mão de obra, o que exigiu esforços de capacitação da população para mitigação dessa lacuna.

Frente a esses desafios, é necessário ver a forma como foram superados. A empresa montou estratégias para lidar com a mudança de cultura, principalmente relacionadas à educação dos seus funcionários, promovendo treinamento à liderança, desde o presidente até a supervisão de fábrica. Isso envolve treinamento de comunicação, educação à diversidade e inclusão e acesso constante ao tema. Suellen relata que "os passos cruciais no início de D\&I são educar e sensibilizar a população e chamar as pessoas para assumir um compromisso pessoal de diversidade e inclusão e muito treinamento, principalmente da liderança, porque são as pessoas que vão moldar o comportamento da organização." Os líderes são catalisadores de um ambiente mais aberto, produtivo e eficiente.

Para a empresa, diversidade e inclusão devem ser encaradas para lidar com todos os desafios. Se não tem mão de obra diversa na região que se quer atuar, a empresa não se justifica a partir disso, ela treina as pessoas para que as metas de diversidade sejam alcançadas. Para atingir a meta de aumentar cerda de $20 \%$ da presença de mulheres nos cargos técnicos, industriais corporativos e de liderança, foi montado um plano de desenvolvimento de carreira para mulheres, denominado Power of Choice, com o objetivo de preparar as profissionais para atingir posições seniores, além de trabalhar o empoderamento feminino. Além disso, a empresa criou um curso de capacitação exclusivo para mulheres em Frutal (MG), em parceria com o Serviço Nacional de Aprendizagem Industrial (Senai), com o objetivo de gerar mão de obra qualificada na região: "Estamos fazendo o caminho inverso em relação a outras empresas: ao invés de irmos ao mercado procurar profissionais com as habilidades necessárias, estamos preparando a mão de obra feminina futura", ressalta a entrevistada. 
Outra maneira de superar os desafios apresentados e de tornar a empresa mais diversa foi mudar a forma de divulgação das vagas. Uma das perguntas do roteiro da etapa 1 foi "como a implementação do programa afetou o recrutamento e seleção dos empregados?" A entrevistada então relatou que precisou desafiar alguns processos e políticas de $\mathrm{RH}$, tornando o processo de recrutamento e seleção mais inclusivos, primeiro expandido os locais de busca de candidatos, indo atrás de uma população mais diversa e reformulando a divulgação de vagas, através uma linguagem mais inclusiva, a fim de minimizar o impacto dos vieses nos processos de recrutamento e seleção.

Ao questionar sobre qual área da empresa ficou inicialmente responsável pelo tema, a entrevistada relatou que o $\mathrm{RH}$, Compliance e a área de comunicação tinham algumas políticas sobre o tema, mas que só com a criação da área de diversidade e inclusão o programa começou a ser implementado. Mas a área ainda trabalha em conjunto e integrada com esses outros setores. Esse é um fator importante para usar o marketing interno como ferramenta de implementação e gestão de um programa de diversidade, pois um dos conceitos de marketing interno fala sobre coordenação interfuncional e integrada HEMAIS; OLIVEIRA; CASOTTI, 2013).

Uma vez entendido o que motivou a empresa, quais foram os principais desafios, de que forma o programa afetou o recrutamento e seleção dos candidatos e que áreas ficaram responsáveis pelo programa, será analisado quais ferramentas foram utilizadas na implementação e de que forma as ações e o engajamento da empresa são comunicados aos funcionários.

Em relação às ferramentas de implementação, além do código de conduta e a política de diversidade, a empresa promove diversos eventos voltados a sensibilização e educação a diversidade, como palestras, eventos em datas comemorativas etc. Recentemente, a empresa promoveu a semana da diversidade, onde trouxe um conteúdo informativo e educativo aos funcionários durante toda a semana e com temas diferentes para cada dia. A empresa conta também com seus grupos de afinidade, a fim de aproximar os funcionários a temas de seus interesses.

As palestras costumam trazer um impacto forte nos funcionários, podendo desenvolver a empatia. Empatia pode ser definida como a capacidade de aprender sentimentos e identificar-se com a perspectiva do outro, reagindo a essa compreensão e sentimentos. Percebe-se com isso que o conceito de empatia está relacionado com a noção de sensibilidade intercultural, abordada no capítulo dois, e pode ajudar os funcionários a evoluírem nos níveis de sensibilidade intercultural. 
A estruturação dos grupos de afinidade, segundo Suellen, ajudam a melhorar o ambiente de trabalho, trazendo identificação e segurança psicológica para as pessoas. Além disso, os grupos de afinidade amplificam a comunicação da empresa com os funcionários, mostrando que conseguem enxergar necessidades dos funcionários que precisam ser satisfeitas. Essas necessidades também podem ser necessidades dos clientes externos e que, ao estimular esses grupos de afinidade a empresa também está se orientando para o mercado (HEMAIS, OLIVEIRA, CASOTTI; 2013).

Dito isso, a entrevistada também foi questionada sobre os meios de comunicação utilizados para informar os funcionários do engajamento da empresa. Ela relatou que o comitê regional de D\&l é responsável pela definição de estratégias e os motivadores de cada pilar e que, a partir dessas estratégias, a comunicação é direcionada com mais eficiência. Essa comunicação é feita principalmente por e-mail corporativo e na fábrica chega através de informativos em murais e banners, além de grupos no WhatsApp e a intranet.

Foi relatado também que as pautas e políticas de diversidade e inclusão da empresa são divulgadas já no processo de recrutamento, quando os candidatos entram na empresa sabendo que a diversidade faz parte da cultura e que a inclusão é vivenciada diariamente, mostrando que ele está em um ambiente acolhedor. $\mathrm{Na}$ integração desses funcionários, há uma conversa sobre como a empresa vivencia a diversidade, com o objetivo de educar esses novos funcionários.

\subsubsection{Impacto interno}

Uma vez analisados os pontos anteriores, a próxima etapa consiste em entender o impacto interno percebido pela entrevistada. Inicialmente, são discutidas as respostas sobre o impacto da gestão da diversidade na imagem interna da empresa e a gestora apontou que o programa afetou positivamente essa imagem.

É importante que a imagem da empresa seja afetada internamente pois mostra que o engajamento com o tema é real e não apenas uma ação para atrair clientes que se preocupam com a pauta da diversidade.

A empresa busca atender as necessidades e os interesses dos funcionários, para que eles não estejam apenas envolvidos, mas que também façam parte da ação e percebam os benefícios de fazer parte. Suellen relata que 
"percebe um orgulho muito grande dos funcionários pela empresa estar se movimentando em direção a esse tema."

No marketing interno, existe um conceito sobre orientação de mercado e satisfação do cliente, onde o funcionário ao se sentir não só envolvido, mas também pertencente, pode desenvolver esse olhar ao lidar com o cliente externo e isso impacta nos resultados da empresa (HEMAIS; OLIVEIRA; CASOTTI; 2013).

Sabendo que, de acordo com a Suellen, a imagem interna da empresa foi afetada positivamente, buscou-se entender de que forma o programa impactou na satisfação e motivação dos funcionários. A empresa ainda irá rodar um senso que dará uma visão mais concreta e em números exatos sobre a percepção do público interno. Porém, a entrevistada Suellen apontou que recebe diversos feedbacks dos funcionários, por meio dos quais eles se mostram cada vez mais engajados. Ela relata também a satisfação das pessoas em trabalhar na Ball:

Eu fiz uma integração na fábrica de Frutal e uma funcionário me enviou um e-mail que me emocionou bastante, falando que está há 20 anos no mercado e que nunca esteve tão em paz de entrar para uma empresa, porque nunca se sentiu tão respeitada e valorizada pelo que é.

Outro ponto analisado foi que a empresa já recebeu o selo Forbes de melhor empresa para se trabalhar para o público LGBTQIA+, nos Estados Unidos. Ou seja, ela busca trazer um ambiente acolhedor e seguro, para que as pessoas se sintam confortáveis e consigam expor suas opiniões sem medo e consequentemente se sentirem mais satisfeitas e motivadas.

Isso mostra o quanto o programa de diversidade está integrado ao marketing interno. Outra definição de marketing interno dada previamente neste estudo dizia que são ações de marketing para atingir a satisfação dos funcionários, buscando atrair, desenvolver, motivar e reter empregados qualificados, de forma a satisfazer suas necessidades, através de uma filosofia que olha para o funcionário como cliente, tendo uma abordagem complementar à gestão de pessoas (HEMAIS; OLIVEIRA; CASOTTI; 2013).

Para entender esse impacto de forma mais concreta, foi perguntado à entrevistada se havia notado diferença nas avaliações de desempenho após a implementação do programa. Como o programa de diversidade da Ball é recente e ainda está em processo de estruturação, essa percepção só será possível após 
os resultados do censo, mas com os relatos dos funcionários foi possível notar que o orgulho que as pessoas sentem em trabalhar na Ball se reflete na motivação de querer dar o seu melhor, entendendo que ali vale a pena.

Em suma, esses pontos mostram que um programa de diversidade tem impactos positivos internamente e afetam na motivação e satisfação dos funcionários, o que os retêm na empresa, podendo causar também um impacto positivo externamente.

\subsubsection{Impacto externo}

Para entender de que forma a entrevistada percebeu um impacto externo de uma gestão de diversidade, duas perguntas foram feitas. Antes de analisar as respostas, vale ressaltar que o marketing interno quer promover nos funcionários um olhar para o cliente (HEMAIS; OLIVEIRA; CASOTTI; 2013). Sendo assim, tende-se a pensar que, através dos dados analisados sobre os impactos positivos do programa internamente, haveria também um impacto positivo externamente. Entretanto, não há como afirmar isso, pois, como dito anteriormente, o programa de diversidade da Ball é recente e a empresa está focando na estruturação e educação interna, para assim poder realizar estratégias externas que gerem impactos positivos. Mesmo sem dados concretos em relação a esse impacto externo, a empresa busca ações em que sua cadeia de valor esteja alinhada com os valores da empresa, incluindo a pauta de diversidade e inclusão. Ela faz isso mantendo relações com stakeholders que abraçam a mesma causa e que não afetem a imagem da empresa e o que ela está construindo internamente com o programa de diversidade e inclusão.

A primeira pergunta do tópico foi "houve alguma mudança na relação com os clientes externos após a empresa ter se mostrado engajada com a inclusão e diversidade?". A entrevistada apontou que em um futuro próximo a empresa terá ações coordenadas, porque seus clientes já se posicionam fortemente, e isso vai ser mais um braço de parceria que a empresa terá, impactando diretamente a imagem de todos os envolvidos externamente.

Outro ponto perguntado foi se a entrevistada achava que o programa havia afetado a imagem externa da empresa. Ela afirmou que alguns projetos foram noticiados na mídia, como a parceria com o Senai para capacitação de mulheres para a fábrica de Frutal (MG) e isso ajudou na visibilidade, mas que eles ainda não têm um marketing sobre isso justamente por estarem focados nas demandas internas. 
A análise dos dados obtidos na primeira etapa de pesquisa mostrou que, mesmo que indiretamente, a implementação do programa de diversidade teve impactos internos e externos que atraíram, desenvolveram, motivaram e retiveram os empregados. Percebeu-se também que a empresa utiliza estratégias de marketing interno, como uma coordenação interfuncional e integrada, treinamento trazendo uma visão para o mercado e um recrutamento mais diversificado, buscando atingir públicos diversos. Isso mostra que as estratégias de marketing interno podem ser aliadas no momento de tornar um programa de diversidade em um case de sucesso, com funcionários e clientes motivados e satisfeitos.

\subsection{Percepção dos funcionários}

O objetivo da entrevista direcionada ao grupo 2 foi entender de que forma o programa de diversidade afetou o seu trabalho. Dessa forma, foi possível fazer um contraponto entre o impacto interno percebido pela gerente entrevistada e o que de fato os funcionários têm a dizer. Esse tópico está dividido em três subtópicos, sendo eles a percepção de importância de abordar o tema, o impacto no dia a dia e a percepção e conhecimento do programa.

\subsubsection{Percepção da importância de abordar o tema}

O primeiro ponto a ser analisado neste tópico são as respostas à pergunta "Você considera importante a empresa ser engajada com diversidade? Isso te motiva? Por quê?" Todos os respondentes afirmaram que era um ponto importante e a maioria das mulheres apontou como motivacional, principalmente as que trabalham diretamente nas fábricas e que exercem funções consideradas masculinas pela sociedade. Amanda relata que "é muito difícil estar trabalhando em uma empresa onde você gosta da sua função, mas não tem perspectiva de crescimento por se tratar de uma vaga masculina, ainda mais hoje em dia, onde a gente tem tanta tecnologia. Então acho esse engajamento muito importante e isso é uma motivação enorme para mim". Esse foi um ponto bastante relatado pelas mulheres: ter perspectiva de crescimento e formação de carreira dentro da empresa, como relata Mariany: "Eu estou vendo a possibilidade de crescer num ambiente que é majoritariamente masculino, então está sendo incrível."

Percebe-se que esse engajamento transpassa uma sensação de pertencimento e orgulho, além de valores fortes que dão um propósito maior ao trabalho. 
Essas respostas se mostram alinhadas com algumas das motivações apontadas no subitem 4.1.1, principalmente quando apontam tornar o ambiente de trabalho mais acolhedor, mais seguro e mais representativo da sociedade. Além de se relacionarem diretamente a um conceito do marketing interno sobre satisfação e motivação, onde uma de suas principais funções é satisfazer e motivar os funcionários, para que isso se reflita nos resultados da empresa (HEMAIS; OLIVEIRA; CASOTTI; 2013).

Em contrapartida, ao questionar os entrevistados sobre o quão importante foi saber que o empregador era comprometido com diversidade no momento de escolher o emprego atual, apenas uma entrevistada apontou isso como um fator de importância. Entretanto, os outros entrevistados disseram que não foi o fator principal no momento da procura, mas, ao saber que a empresa tinha um engajamento, isso se mostrou como um fator extra e um ponto atrativo.

De certa forma, essas respostas mostram o impacto que a empresa teve na percepção dos funcionários sobre diversidade, visto que todos mostraram isso como um fator importante e motivacional, mas foram poucos os que apontaram como um fator importante no momento de escolher um emprego, conforme o relato a seguir mostra:

\footnotetext{
Eu tenho que admitir que não, porque infelizmente a gente vive num contexto em que as empresas manejam o que oferecem de acordo com a busca econômica delas, então eu busquei um lugar que primeiramente me atraísse em outras questões. Mas desde o primeiro momento a Ball me passou uma imagem de valorização do funcionário e isso com certeza foi um fator relevante para eu escolher ficar. (Raphael)
}

\subsubsection{Impacto no dia a dia}

Tendo entendido o grau de importância do programa de diversidade para os entrevistados, buscou-se entender qual é o impacto concreto desse no dia a dia deles. A maioria dos entrevistados apontou que, com o programa de diversidade, a comunicação ficou melhor, o que é visto na seguinte resposta: "Eu 
senti que com o programa de diversidade a comunicação ficou mais fluida e menos estressante, o que melhora a convivência no dia a dia. (Saulo)"

Muitos dos entrevistados disseram não ter uma relação com clientes externos, mas pode-se perceber que, mesmo assim, o programa e as ações de sensibilização fomentaram a empatia e mudaram sua percepção, permitindo que cada um reconhecesse seus privilégios e se relacionasse melhor com pessoas que não têm a mesma história e não tiveram a mesma trajetória. Esse ponto pode ser relacionado com o conceito de orientação para o mercado e satisfação do cliente, nesse caso o cliente sendo o funcionário (HEMAIS; OLIVEIRA; CASOTTI; 2013).

Outra resposta a esse respeito foi do entrevistado Vandson:

O conhecimento trouxe mais clareza para todo mundo, o que eu acredito ter facilitado a comunicação entre todos nós, principalmente pela implementação de uma linguagem nova que facilita 0 tratamento das pessoas. Ainda mais a gente que trabalha em um ambiente que tem muito ruído, então as vezes a gente fala alguma coisa que pode ser mal interpretado e agora isso facilitou essa dinâmica.

Esse impacto também pode ser analisado ao perguntar se os entrevistados já haviam trabalhado em outra empresa que não tivesse um programa de diversidade, a fim de entender se notaram alguma diferença na forma da empresa se comunicar e tratar clientes e funcionários. Através de algumas das respostas, pode-se perceber que outras empresas não tinham um programa de diversidade, nem pautas sobre o tema internamente ou que o programa da empresa atual era mais concreto e não apenas para o marketing externo, que as empresas que não tinham um programa tinham a comunicação mais difícil, o ambiente era mais pesado e menos propício à exposição de ideias, pois os funcionários não se sentiam a vontade e que na Ball existe uma sensação de pertencimento, onde todos estão no mesmo barco, apesar das suas diferenças. Raphael relata que trabalhou em uma grande empresa que dizia ter um programa de diversidade estruturado, mas que internamente via coisas totalmente contrárias ao que era pregado: 
Eu já estive em uma empresa multinacional de grande porte que tem um programa de diversidade e não vive isso no seu dia a dia, é totalmente de fachada. A comunicação em uma empresa que vive de verdade isso é totalmente diferente, é um ambiente mais respeitoso onde você se sente confortável de se comunicar e dar as suas ideias sem ter medo de ser hostilizado.

A empresa que eu trabalhava já tinha toda uma estrutura e a Ball ainda está se estruturando nesse aspecto, mas está muito a frente dessa empresa.

Essa comparação de experiência em empresas diferentes mostra que o impacto percebido pelos entrevistados foi positivo, principalmente no que diz respeito ao ambiente acolhedor de trabalho.

Por fim, buscou-se entender o impacto no dia a dia dos entrevistados e de que forma o trabalho era valorizado e se existia algum programa de reconhecimento não financeiro na empresa. Pode-se perceber que a empresa promove alguns programas e movimentos que fazem os funcionários se sintonizarem e se sentirem motivados, como um sistema no qual os funcionários podem agradecer ou parabenizar as pessoas por alguma coisa e os feedbacks foram apontados pela maioria como sendo um fator motivador. Quando ocorre um evento especial, como promoção de funcionário, destaque em algum projeto, isso é divulgado internamente para a empresa inteira.

Além disso, a empresa bonifica os funcionários através de almoço especial, brindes e reconhecimento por tempo de casa.

\subsubsection{Percepção e conhecimento sobre o programa}

Uma vez percebido o grau de importância e o impacto no dia a dia dos entrevistados, buscou-se entender qual era o grau de conhecimento que eles tinham do programa, em questões técnicas, como divulgação, por exemplo. Dessa forma, pode-se analisar como a implementação se deu, conectando com os conceitos de marketing interno.

O primeiro ponto foi entender de que forma o programa era divulgado internamente. As respostas apontaram que era feito através de e-mails, comunicados, ações, palestras, grupos de afinidade, grupo de WhatsApp da 
empresa, adesivamente e instalação de banners na fábrica, "boca a boca" e intranet da empresa. As respostas não se diferem das respostas a essa pergunta dada pela gerente da empresa. O que ficou claro nesse tópico foi a importância de uma boa comunicação interna e uma boa divulgação do programa, apesar de alguns funcionários apontarem que essa divulgação aparenta ser mais efetiva na área administrativa da empresa do que na fábrica. A comunicação interna estimula comportamentos nos funcionários, então, entende-se que a mesma deve ser bemfeita (HEMAIS; OLIVEIRA; CASOTTI; 2013).

Foi perguntando aos entrevistados se eles tinham conhecimento de quais eram os setores responsáveis pelo programa de diversidade. Muitos apontaram que era o $\mathrm{RH}$, mas outros afirmaram existir uma integração entre a área e o setor de comunicação, entretanto, apenas um funcionário sabia que existia um setor específico de diversidade e inclusão na empresa, que trabalha junto com o $\mathrm{RH}$ e com comunicação. Com isso, podemos afirmar que a combinação entre $\mathrm{RH}$ e comunicação vem se mostrando importante para conectar as práticas de recrutamento propostas do referencial teórico e nas próprias respostas dos entrevistados do grupo 1, com as noções de marketing interno, em questões de olhar para o funcionário como cliente e buscar suprir suas necessidades.

Em seguida, foi perguntado de que forma era feita a divulgação externa do programa e se ela condizia com a realidade que era praticada na empresa. Como a empresa ainda está estruturando seu programa e está focada em ações de sensibilização internas, os entrevistados afirmaram não saber muito bem como é feita essa divulgação externamente. Entretanto foi apontado por alguns funcionários que existia uma divulgação através de Linkedln, site da empresa e em redes sociais e que estaria de acordo com o que é praticado internamente:

Agora que existe um setor específico de diversidade e inclusão, eu vejo isso sendo divulgado nos processos seletivos e na divulgação das vagas pelo Linkedln. Eles estão fazendo processo seletivo direcionado, para aumentar a quantidade de mulheres atuando na fábrica, aumentar a quantidade de PCDs e capacitá-los e isso está sendo divulgado nas redes sociais. (Nathalia)

O último questionamento foi feito para saber se existia algum tipo de treinamento de sensibilização à diversidade dentro da empresa. Os entrevistados 
- nenhum com cargo de liderança - apontaram que não, mas que no momento de integração existe um treinamento sobre diversidade e sobre como a empresa aborda esses assuntos, mostrando que a diversidade faz parte da cultura da empresa: "Eu nunca participei por ter pouco tempo na empresa, mas tem a integração que não deixa de ser um treinamento para quem está entrando na empresa." (Mariany)

Entretanto, as palestras e ações propostas foram percebidas como treinamento por conta dos conhecimentos ensinados. Nathalia relata que, com os conhecimentos adquiridos, aprendeu a ter mais cuidado na comunicação, por perceber que alguns termos comumente utilizados podem ser ofensivos. Ou seja, ações de sensibilização não tão formais como treinamentos também passam um conhecimento para os colaboradores e são efetivas e afeta a forma de se comunicar com clientes externos. Isso nos mostra que o treinamento aplicado no contexto de marketing interno, oferece ao funcionário uma visão de mercado (HEMAIS, OLIVEIRA, CASOTTI; 2013).

\subsection{Relação entre as duas etapas da pesquisa}

Por fim, este tópico tem por objetivo comparar as respostas dos dois grupos de entrevistados. Um ponto que ficou claro e marcado nas respostas dos dois grupos é a importância de um ambiente de trabalho acolhedor. Enquanto a gerente apontava buscar tornar o ambiente de trabalho em um lugar que o funcionário se sentisse acolhido e pudesse ser ele mesmo, o grupo 2 afirmou que estar em um ambiente de trabalho assim é algo de extrema importância para o desenvolvimento de relacionamentos, para a abertura e reconhecimento de novas ideias e por questões motivacionais também. Um dos efeitos desejáveis da diversidade é a melhora no clima organizacional, influenciando assim os resultados da empresa (FERNANDES; FERREIRA; LEBARCKY; 2011).

Pode-se dizer então que empresas que aplicam a visão do marketing interno, na qual os funcionários são vistos como clientes com necessidades, têm um retorno positivo deles, onde se sentem valorizados e motivados, o que pode repercutir em resultados da empresa.

As ações de diversidade da empresa fazem com que seus funcionários sejam mais engajados e deem mais importância ao tema. Isso ficou claro quando todos os entrevistados do grupo 2 apontaram considerar importante e motivacional a empresa ser engajada com diversidade. Mas, quando questionado o grau de importância dado para esse fator no momento de escolher seus trabalhos atuais, 
disseram não ser um fator decisivo. No entanto, alguns disseram que, depois de entender a importância do programa e de ver os impactos no dia a dia, isso se tornou um fator importante no momento de escolher um emprego.

Esse impacto pode ser repercutido na relação com clientes externos, relação com colegas, clima organizacional e resultados da empresa.

Um ponto de atenção que deve ser trabalhado na implementação e comunicação do programa são os vícios da empresa, como fragilidades, a fim de não descredibilizar o programa. Esse ponto pode ser melhorado seguindo o plano de equidade proposto no capítulo 2 , onde a empresa determina metas claras de representatividade dos grupos-alvo por cargos.

Por fim, a tabela 4 a seguir, faz um comparativo entre os pontos indicados pelos entrevistados sobre a gestão da diversidade praticada pela empresa e o marketing interno.

Tabela 4: Grau de utilização dos conceitos de marketing interno no programa de diversidade da Ball Corporation

\begin{tabular}{|l|c|}
\hline \multicolumn{1}{|c|}{ CONCEITOS DO MARKETING INTERNO } & $\begin{array}{c}\text { GRAU DE UTILIZAÇÃO NO PROGRAMA } \\
\text { DE DIVERSIDADE DA EMPRESA }\end{array}$ \\
\hline Satisfação e motivação & Alto \\
\hline Orientação para o mercado e satisfação do cliente & Alto \\
\hline Coordenação interfuncional e integrada & Médio \\
\hline Comunicação interna & Alto \\
\hline Treinamento & Alto \\
\hline Recrutamento e seleção & Baixo \\
\hline Avaliação de desempenho e recompensas & \\
\hline
\end{tabular}

Fonte: Elaborado pela autora 


\section{Conclusões}

O presente estudo teve como objetivo analisar de que forma o marketing interno foi utilizado como um meio de implementação e gestão para o programa de diversidade da Ball Corporation. Para isso, foi realizada uma pesquisa exploratória e qualitativa, dividida em duas etapas. A primeira etapa consistiu em uma entrevista com Suellen Moraes, gerente de Diversidade e Inclusão da Ball e a segunda em entrevistas com 7 funcionários da empresa. A partir da análise dos dados coletados, foi possível chegar a algumas conclusões.

Considerando que o programa de diversidade e inclusão da empresa ainda é recente, apesar de já ter políticas relacionadas ao tema estruturada desde 2015, segundo Suellen, o primeiro ponto que se pode observar é que o processo de implementação do programa de diversidade e inclusão da empresa passa por diversos desafios, em especial no Brasil, que parecem ser amenizados ao usar o marketing interno como ferramenta de implementação e gestão de um programa de diversidade, notadamente quando aplicadas junto às estratégias de $\mathrm{RH}$ e do setor de comunicação da empresa. Como observado no capítulo anterior, na tabela 4, mesmo que de maneira não intencional, alguns conceitos de marketing interno, como satisfação e motivação, coordenação interfuncional e integrada, recrutamento e seleção e treinamento, serviram de apoio para estruturar e gerir o programa de diversidade.

Ficou claro que, para os dois grupos de entrevistados, a satisfação e motivação eram pontos importantes. Enquanto na primeira etapa da pesquisa foi observado um olhar para o funcionário como cliente, buscando satisfazer suas necessidades e proporcionar um ambiente psicologicamente seguro, o grupo 2 apontou se sentir seguro, respeitado e, consequentemente, motivado.

Em seguida, percebe-se que ter esse olhar causa impactos no dia a dia dos funcionários, em vários aspectos além da motivação e satisfação. Um deles é na forma de se relacionar com funcionários e com clientes externos. Apesar de não ter sido relatado pelos funcionários contato frequente com estes, podemos afirmar, através do conceito de orientação para o mercado e satisfação do cliente, que a motivação gerada pelo programa pode ter impacto nesses clientes caso 
ocorra uma demanda externa. Entretanto, o foco deve estar na satisfação do cliente interno, e não no externo, para que o programa não perca sua credibilidade.

O conceito seguinte é o de coordenação interfuncional e integrada. A própria justificativa desse conceito diz que o marketing interno não deve ser tratado como uma função especializada (HEMAIS; OLIVEIRA; CASOTTI; 2013). Notou-se que, quando apontado a coordenação integrada para assuntos de diversidade, o principal aliado do marketing interno era o setor de $\mathrm{RH}$ e de comunicação. De fato, conforme apresentado no capítulo dois desse estudo, algumas etapas da implementação do programa de diversidade passam obrigatoriamente pelo $\mathrm{RH}$, principalmente no que tange o recrutamento e a seleção e os treinamentos. Além disso, ressaltam-se também as ações trazidas pelo setor de comunicação, que visa promover um ambiente mais acolhedor, facilitando assim a integração das pessoas. Mas, as estratégias de marketing interno se tornam complementar para o sucesso do programa.

Sem a comunicação interna da empresa, o programa não teria sido efetivamente divulgado, apesar de alguns funcionários terem relatado dificuldade dessa comunicação dentro da fábrica e ela ser mais efetiva no administrativo. Supõem-se, então, que a comunicação interna dá mais força, engajamento e visibilidade para o programa.

Quando abordado o conceito de treinamento, nota-se que é importante a empresa promover treinamentos e palestras de sensibilização pois, de acordo com os dados, essas ações são as que mais causam impactam nos colaboradores. Nessa mesma temática de $\mathrm{RH}$, o outro conceito é o recrutamento e a seleção que é diretamente relacionado às metas de representatividade, além da capacitação da população interna e externa para se alcançar essas metas. Esse é um ponto que também traz credibilidade para o programa pois mostra, de maneira mais concreta e visível, o engajamento da empresa.

Por fim, notou-se que as avaliações de desempenho e recompensas não tiveram um impacto na implementação do programa, segundo o que foi relatado pelos entrevistados, então seria um dos conceitos que não serviriam de ferramenta para a implementação do programa, a não ser que, futuramente a empresa estruture melhor a forma que realiza essas avaliações de desempenho e recompensa.

Conclui-se então que alguns conceitos do marketing interno podem servir de ferramenta estratégica para implementar e gerir o programa de diversidade, em parceria com o setor de $\mathrm{RH}$ e o setor de comunicação, amenizando alguns 
dos desafios através do retorno positivo e do grau de importância percebido pelos funcionários.

\subsection{Implicações gerenciais}

Com base nas análises e considerações anteriormente apresentadas, recomendam-se algumas ações gerenciais, julgadas importantes para o sucesso de um programa de diversidade.

O primeiro ponto é que a empresa deve se atentar e focar em implementar um programa no qual os funcionários possam enxergar os benefícios e que não seja algo para gerar um marketing positivo da empresa externamente. As ações devem ser estruturadas a curto, médio e longo prazo para, eventualmente, ter uma empresa representativa da sociedade e com um ambiente acolhedor para qualquer pessoa. Por isso vale ressaltar a importância de uma coordenação interfuncional e integrada, que facilita na tomada de decisão e engajamento de mais áreas e diretorias.

Em segundo lugar, para que a empresa tenha um olhar para o funcionário como cliente, é importante que os escute e entenda suas necessidades, da mesma forma que é feito com clientes externos. Para isso, percebe-se que os grupos de afinidades são uma boa forma de manter um canal aberto entre empresa e funcionário.

Por fim, entendeu-se que o engajamento da alta liderança é crucial para que o programa tenha credibilidade e que a diversidade faça parte da cultura organizacional, não é à toa que a mudança de cultura foi apontada na primeira etapa da pesquisa como um dos principais desafios. Por isso, é importante que as metas de diversidade façam parte do planejamento estratégico da empresa e a liderança deve ser treinada.

\subsection{Recomendações para novos estudos}

Para estudos futuros, recomenda-se que o total de respondentes que são de níveis gerenciais de empresas envolva líderes de outras áreas; apesar de o foco ser na pessoa que estaria à frente da implementação e gestão do programa de diversidade, seria interessante ver a perspectiva desses outros líderes.

Também seria interessante complementar o estudo com o censo sobre diversidade específico para a América Latina. A empresa realizou uma pesquisa global sobre diversidade para se identificar como as pessoas experenciavam 
inclusão no dia a dia, porém, acabou ficando rasa porque muitos países têm restrições culturais que impedem que seja perguntado uma série de fatores para avaliação.

Por fim, outra recomendação seria realizar a pesquisa apenas com funcionários que tem contato com clientes externos, de forma a entender qual peso deve ser dado ao marketing interno e externo. 


\section{Referências Bibliográficas}

ALVES, M. A; GALEÃO-SILVA, L. G. A crítica da Gestão da Diversidade nas organizações. RAE - Revista de Administração de Empresas. v. 44, n. 3, p. 20 29, Jul/Set 2004.BERRY, L.; PARASURAMAN, A. (1995). Serviços de marketing: competindo através da qualidade (3a ed.). São Paulo: Maltese.CARDOSO, Onésimo de Oliveira. Comunicação empresarial versus comunicação organizacional: novos desafios teóricos. 2005.

CASCIO, W. F. (1995). Managing human resources. New York: McGraw Hill.

COOKE, A. L. Oppression and the workplace: a framework for understanding Diversity Factor, v. 8, n. 1, p. 6. 1999.DE CASSIA MARTINS DOS SANTOS, G; RODRIGUES, I; EMERICK DUTRA, S; DE VASCONCELLOS LAMEIRO DA COSTA, B, Gestão da Diversidade: um estudo entre as "melhores empresas para você trabalhar", Universidade de São Paulo, 2008. Data de consulta: 23 de março de 2020. Disponível em: http://sistema.semead.com.br/11semead/resultado/trabalhosPDF/445.pdf

DEJEAN, F.; HUESCA, A. D.; MERCIER, A. D., Relations Interculturelles et Gestion de la Diversité, IRIPI, Montreal jun. 2017. Disponível em https://iripi.ca/wp-content/uploads/2018/01/Guide-pour-outiller-les-PME.pdf

DEL PRETTE, A. \& DEL PRETTE, Z. A. P. (2001). Psicologia das Relações Interpessoais: vivências para o trabalho em grupo. Petrópolis: Vozes.

FERNANDES, A. R.; FERREIRA, K. A. R.; LEBARCKY, F.V. Gestão da Diversidade e Endomarketing: Existe uma Relação? In: ENANPAD ENCONTRO NACIONAL DOS PROGRAMAS DE PÓS-GRADUAÇÃO EM ADMINISTRAÇÃO, XXXV, 2011. Rio de Janeiro. Anais eletrônicos... Rio de Janeiro: Anpad, 2011. CD-ROM. Disponível em: http://www.anpad.org.br/admin/pdf/GPR3014.pdf

GIL, ANTONIO CAROLOS. Métodos e Técnicas de Pesquisa Social. 5.ed. São Paulo: Atlas, 2007.

GUIMARÃES, M. F.; ARIEIRA, J. O. O Processo de recrutamento e seleção como uma ferramenta de gestão. In: Rev. Ciên. Empresariais da UNIPAR, Toledo, v.6, n.2, jul/dez., $2005 . \quad$ Disponível em:https://www.revistas.unipar.br/index.php/empresarial/article/viewFile/309/280 
HEMAIS, M.; OLIVEIRA, L.; CASOTTI, L.; Marketing Interno e Gestão de Pessoas: Estudos de Caso em Empresas de Serviços. Revista Gestão \& Tecnologia, vol.13, n. 3, p. 101-127, 2013.

HUNT, V; YEE, L; PRINCE, S; DIXON-FYLE, S. A diversidade como alavanca de performance, McKinsey \& Company, 2018. Disponível em: https://www.mckinsey.com/business-functions/organization/ourinsights/delivering-through-diversity/pt-br

JÉZÉQUEL, M., "Pour une gestion efficace, équitable et proactive des accommodements 》, Gestion, 2008/2 (Vol. 33), p. 66-72. DOI : 10.3917/riges.332.0066. Disponível em: https://www.cairn.info/revue-gestion2008-2-page-66.htm

JONSEN, K.; MAZNEVSKI, M. L.; SCHNEIDER, S.C. Diversity and its not so diverse literature: An international perspective. International Journal of Cross Cultural Management, v. 11, n. 1, pp. 35-62, 2011.

KOTLER, P. Princípios de Marketing. 9. ed. Rio de Janeiro: LTC, 1999.

MACCALI, N.; KUABARA S. S. P.; TAKAHASHI W. R. A.; ROGLIO DE DÉA K.; BOEHS M. DE TOLEDO. S. As práticas de recursos humanos para a gestão da diversidade: a inclusão de deficientes intelectuais em uma federação pública do Brasil. RAM, Revista de Administração Mackenzie vol.16 no.2, São Paulo, 2015. Disponível em: https://doi.org/10.1590/167869712015/administracao.v16n2p157-187

MOR BARAK, M. Managing diversity: Toward a globally inclusive workplace. 2. ed. Thousand Oaks: Sage Publications, 2011.NARVER, J. C.; SLATER, S. F. The effect of a market orientation on business profitability. Journal of Marketing, v. 54, n. 4, p. 20-35, 1990.

PESSANHA, DE LIMA. I. Marketing Interno como Ferramenta de Implementação de um Programa de Diversidade. Trabalho de Conclusão de Curso (Graduação em Administração de Empresas) - Departamento de Administração: Pontifícia Universidade Católica do Rio de Janeiro. Rio de Janeiro, 2020

PIMENTA, M. L.; DA SILVA A. L. Integração Interfuncional: considerações a respeito de Marketing e Logística. In: ENANPAD - ENCONTRO NACIONAL DOS PROGRAMAS DE PÓS-GRADUAÇÃO EM ADMINISTRAÇÃO, XXXIV, 2010. Rio de Janeiro.. Anais eletrônicos... Rio de Janeiro: Anpad, 2010. CD- ROM. Disponível em: http://www.anpad.org.br/admin/pdf/gol1149.pdf 
PRESOTTI, L. Gerenciar a diversidade cultural nas organizações: caminhos para a inclusão. Dissertação de Mestrado Não Publicada. Pós-Graduação em Psicologia Social, do Trabalho e das Organizações, Universidade de Brasília. 2011.

RAFIQ, M.; AHMED, P. K. (1993). The scope of internal marketing: defining the boundary between marketing and human resource management. Journal of Marketing Management, 9(3), 219-232.

SEU DINHEIRO. Maior Diversidade nos nossos quadros de liderança vai gerar resultados maiores, diz presidente do Magazine Luiza, 2020. Disponível em: https://www.seudinheiro.com/2020/empresas/maior-diversidade-nos-nossosquadros-de-lideranca-vai-gerar-resultados-maiores-diz-presidente-do-magazineluiza/

TORRES, C. V.; PÉREZ-NEBRA, A. R. Diversidade cultural no contexto organizacional. In: ZANELLI, J. C., BORGES-ANDRADE, J. E., BASTOS, A. V.B. (Org.). Psicologia, Organizações e Trabalho no Brasil. Porto Alegre: Artmed, 2004.

ZIKMUND, William G. Princípios da pesquisa de marketing. São Paulo: Thomson, 2005. 


\section{APÊNDE 1: ROTEIRO DE ENTREVISTA COM O GRUPO 1}

Cargo:

Área:

Tempo de atuação na empresa onde trabalha:

Tempo de atuação com diversidade na empresa onde trabalha:

1) O que motivou a empresa a fazer um trabalho de sensibilização sobre a diversidade?

2) Como o tema sobre diversidade começou a ser abordado?

3) Quais foram os principais desafios encontrados no processo de implementação do programa de diversidade da empresa? De que forma eles foram superados?

4) Quais ferramentas foram utilizadas nessa implementação?

5) Como é feita a comunicação a respeito do engajamento da empresa aos seus funcionários e clientes externos?

6) Houve alguma mudança na motivação e satisfação dos funcionários após a implementação do programa de diversidade?

7) Houve alguma mudança na relação com os clientes externos após a empresa ter se mostrado engajada com a inclusão e diversidade?

8) Isso afetou a imagem interna e externa da empresa? Se sim, como?

9) Qual área da empresa ficou, inicialmente, responsável pelo tema?

10) Como a implementação do programa de diversidade afetou o recrutamento e a seleção dos empregados da empresa?

11) Após a implementação do programa de diversidade, houve alguma alteração na avaliação de desempenho dos funcionários?

12) Você acredita que a comunicação interna pode ser uma ferramenta para mitigação de possíveis conflitos gerados na implementação de um programa de diversidade?

13) Na sua visão, qual a forma ideal de se implementar e gerir um programa de diversidade? 
14) Você acredita que que a gestão da diversidade pode ser um desafio, principalmente para as empresas brasileiras? 


\section{APÊNDE 2: ROTEIRO DE ENTREVISTA DO GRUPO 2}

Gênero:

Idade:

Cargo:

Área:

Tempo de atuação na empresa onde trabalha:

1) Qual é a sua percepção sobre o engajamento da empresa com a diversidade?

2) Você considera esse engajamento importante? Isso motiva você? Por quê?

3) O comprometimento da empresa com a diversidade foi um fator relevante quando você estava buscando seu trabalho atual?

4) O programa de diversidade da empresa afetou a sua forma de se relacionar com os outros funcionários e com os clientes externos?

5) Como é feita a divulgação desse programa internamente?

6) O que você achou da forma que essa divulgação foi feita?

7) Como é feita a divulgação desse programa externamente? Condiz com a realidade do que é praticado internamente?

8) Existe algum tipo de treinamento e sensibilização à diversidade na empresa?

9) Existiu "reciclagem" sobre algum procedimento interno após a implementação do programa de diversidade na empresa?

10) Como foi sua experiencia no processo de recrutamento? Você se sentiu confortável com os questionamentos?

11) Fizeram alguma pergunta específica sobre suas características físicas e/ou demográficas, como gênero, idade, endereço, etc.?

12) Existe algum programa de reconhecimento não financeiro na empresa?

13) De que forma você sente seu trabalho sendo valorizado na empresa?

14) Você acredita que a empresa traz no seu dia a dia o que prega sobre diversidade e inclusão? 
15) As avaliações de desempenho são reconhecidas na trilha de carreira?

16)Quais setores da empresa são responsáveis pelo programa de diversidade?

17) Você já trabalhou em alguma outra empresa que não tinha programa de diversidade? Notou alguma diferença na comunicação da empresa com seus clientes internos (funcionários) e externos? 


\section{APÊNDE 3: RESPOSTAS ENTREVISTA GRUPO 1}

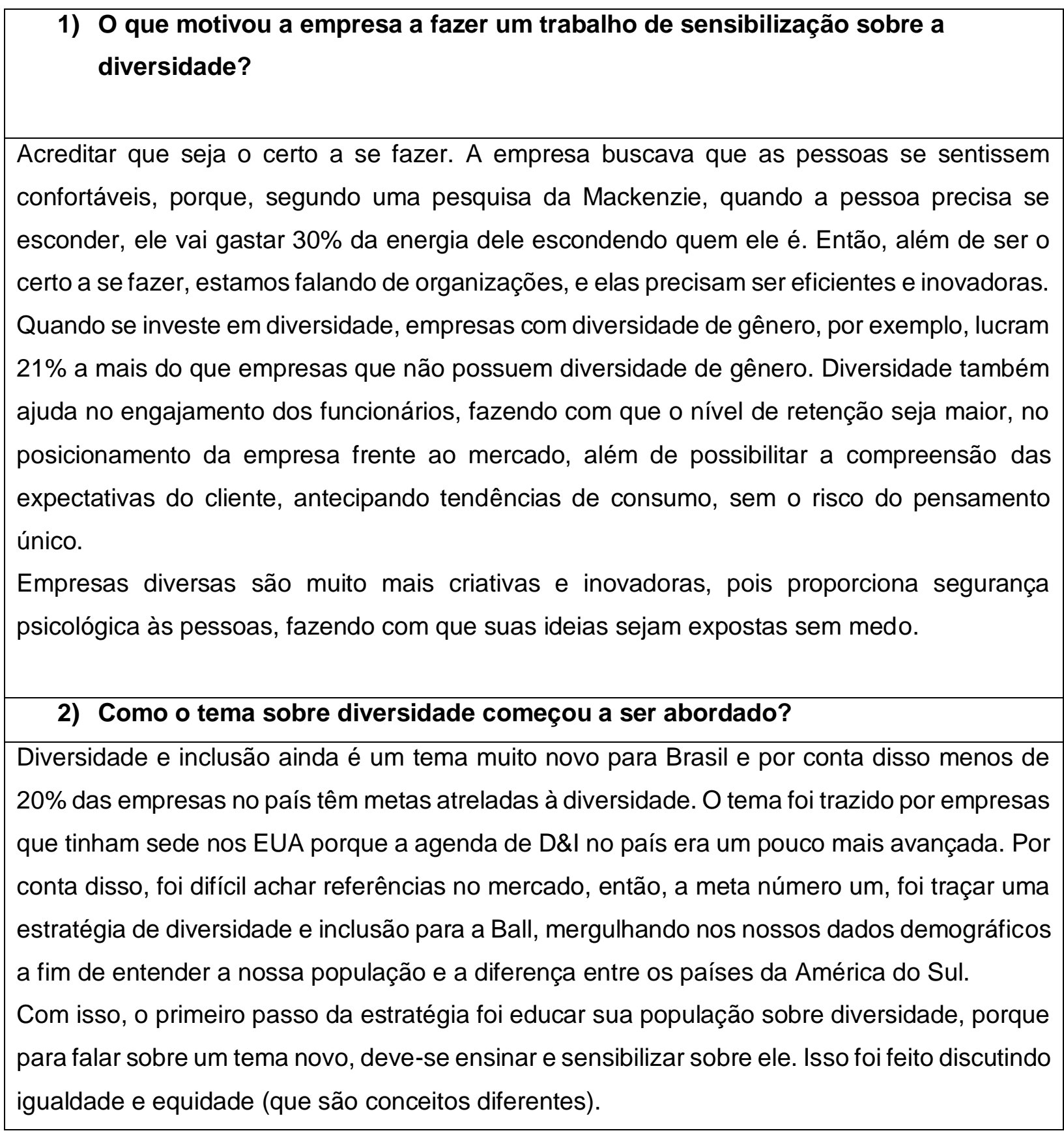


O segundo passo foi treinamento da liderança da empresa, desde o presidente até a supervisão de fábrica, porque a missão de D\&I na Ball é prover oportunidades e ferramentas para que todos possam prosperar em suas carreiras independente de sexo, gênero, orientação sexual, raça, promovendo a cultura do pertencimento, que está muito ligada a inclusão.

Ou seja, os passos cruciais no início de D\&l: educar e sensibilizar sua população e chamar as pessoas para assumir um compromisso pessoal de diversidade e inclusão e muito treinamento, principalmente da liderança, porque são as pessoas que vão moldar o comportamento da organização.

\section{3) Quais foram os principais desafios encontrados no processo de implementação do programa de diversidade da empresa? De que forma eles foram superados?}

Mudança de cultura. Leva tempo e não tem fórmula milagrosa, então tem que se manter um fluxo constante de informação.

Outro desafio é a restrição de mão de obra. A Ball é uma indústria e apesar de ter um processo produtivo automatizado, ela é predominantemente masculina, com uma média de $10 \%$ de mulheres nas fábricas. E por que isso acontece? Será que é um viés inconsciente da liderança ou será que não tem mulher disponível no mercado para ocupar esses cargos? Pensando nisso, a Ball, em parceria com o Senai, capacitou mulheres na região de Frutal, em Minas Gerais, para atingir a meta de ter $30 \%$ da população da fábrica da região feminina.

Então, os maiores desafios é se desafiar como organização, para fazer a pauta de diversidade e inclusão sair do papel.

\section{4) Quais ferramentas foram utilizadas nessa implementação?}

Foi feita uma pesquisa global sobre diversidade, que foi realizada em todas as regiões para se identificar como as pessoas experenciavam inclusão no dia a dia e ela trouxe também um retrato da nossa população. O problema foi que, por ter sido em âmbito global, a pesquisa acabou ficando muito rasa porque muitos países têm restrições que impede que seja perguntado uma série de coisas para avaliação, como orientação sexual, por exemplo. A pesquisa trouxe uma quantidade de dados, mas os dados não eram tão apurados, por isso a Ball vai fazer um censo específico para a América do Sul ainda esse ano.

5) Como é feita a comunicação a respeito do engajamento da empresa aos seus funcionários e clientes externos?

Como a área ainda está começando, o foco é no engajamento da população, então, internamente, a área de comunicação faz todo o suporte para esse engajamento. O comitê 
regional de D\&I é responsável pela definição de estratégia e os motivadores de cada pilar, que são pessoas com deficiência, raça e etnia, mulheres e LGBTQIA+.

Externamente a empresa no momento trabalha comunicando suas ações, metas e compromissos com diversidade em matérias de jornal. Futuramente haverá projetos com clientes engajados com diversidade.

\section{6) Houve alguma mudança na motivação e satisfação dos funcionários após a implementação do programa de diversidade?}

Sim, mas a percepção mais palpável será possível quando o senso rodar na América do Sul. Mas o que eu posso te dizer é que a gente percebe um orgulho muito grande dos funcionários pela empresa estar se movimentando em direção a esse tema. Eu recebo inúmeros e-mails e feedbacks dos funcionários se dizendo engajados, querendo ajudar. Eu fiz uma integração na fábrica de Frutal e uma funcionário me enviou um e-mail que me emocionou bastante, falando que está há 20 anos no mercado e que nunca esteve tão em paz de entrar pra uma empresa, porque nunca se sentiu tão respeitada e valorizada pelo que é. Então a gente já percebe um orgulho muito grande. Toda vez que a gente posta algum conteúdo sobre diversidade e inclusão, as pessoas compartilham nas suas redes e os eventos de D\&I têm uma adesão muito grande.

\section{7) Houve alguma mudança na relação com os clientes externos após a empresa ter} se mostrado engajada com a inclusão e diversidade?

O nosso próximo passo é afetar nossa cadeia de valor, é um movimento natural das empresas. Quando se trata de sustentabilidade, trabalhamos muito em rede, então a Ball tem projetos tanto com fornecedores quanto com clientes. Em um futuro muito próximo teremos ações coordenadas, porque os nossos clientes já são clientes que se posicionam fortemente, e isso vai ser mais um braço de parceria que vamos ter. E por exemplo, quando eu olho para o Ball como fornecedor, pensamos em como vamos promover diversidade na nossa cadeia de fornecedores? Eu valorizo empreendedorismo feminino? Dos meus terceiros, eu vou baixar uma regra pedindo que eles tenham $\mathrm{x} \%$ de mulheres?

Primeiro a gente está arrumando a casa para depois darmos o passo para fora, envolvendo toda nossa cadeia de valor.

8) Isso afetou a imagem interna e externa da empresa? Se sim, como? Muito! Internamente, como já havia comentado, recebemos diversos feedbacks sobre o que a Ball representa para os funcionários. 
9) Qual área da empresa ficou, inicialmente, responsável pelo tema?

A área de diversidade na Ball não é RH e não é Compliance, é a área de D\&I. Tanto que o report da área é diretamente ao CEO. Isso dá independência para a área, porque ajuda a desafiar e dar mais responsabilidade as outras áreas.

10) Como a implementação do programa de diversidade afetou o recrutamento e a seleção dos empregados da empresa?

A gente precisou desafiar alguns processos e políticas de $\mathrm{RH}$. A Ball tem um projeto global de revisão de políticas e processos de $\mathrm{RH}$ e essa força tarefa é formada por pessoas de diferentes áreas de $\mathrm{RH}$ e $\mathrm{D \& l}$, revisando desde os processos de recrutamento e seleção, passando pelo processo de mérito, promoção e desenvolvimento de carreira. A gente precisou tornar o processo de recrutamento e seleção mais inclusivos, pensando fora da caixa. Começamos a expandir o range de busca de candidato, indo atrás de uma população mais diversa. Reformulamos as vagas que tínhamos publicadas no Linkedln para usar uma linguagem mais inclusiva a fim de minimizar o impacto dos vieses nos processos de $\mathrm{RH}$.

11) Após a implementação do programa de diversidade, houve alguma alteração na avaliação de desempenho dos funcionários?

O que eu tenho dos funcionários é um feedback informal, porque eu só vou conseguir mapear isso com os resultados da pesquisa e a pesquisa eu só vou implementar em julho. Mas esse feedback nos mostra um orgulho dos funcionários em trabalhar na empresa, impactando diretamente no seu desempenho de trabalho.

12) Você acredita que a comunicação interna pode ser uma ferramenta para mitigação de possíveis conflitos gerados na implementação de um programa de diversidade?

Com certeza, ainda mais nesse começo que você precisa fazer uma educação e sensibilização muito forte, principalmente quando se trata de diversidade, porque muitas pessoas por falta de conhecimento, principalmente na liderança não se sente confortável para falar.

13) Na sua visão, qual a forma ideal de se implementar e gerir um programa de diversidade?

Precisa ter uma liderança comprometida para se liderar pelo exemplo. 
Medir o seu sucesso, com KPl's. com metas e métricas para medir o sucesso do que se está sendo feito é de fato efetivo, se todas as ações que estão sendo implementadas estão surtindo o efeito que a gente quer. Porque quando não se mede a eficácia das suas ações, pode se estar investindo energia em uma estratégia que não vai dar em nada.

\section{4) Você acredita que que a gestão da diversidade pode ser um desafio, principalmente para as empresas brasileiras?}

Eu acho que é um caminho natural para as empresas brasileiras, apesar do longo percurso que ainda temos que percorrer, ainda mais quando a gente compara com empresas norte americanas, que já estão bem mais avançadas. Mas eu acho que assim como foi o movimento de sustentabilidade há uns anos, diversidade está no mesmo caminho, principalmente nesse contexto pós pandemia, que as pessoas estão mais empáticas, a questão da saúde mental sendo mais discutida, lideranças mais humanizadas, então eu acho que diversidade é um assunto que veio para ficar e que realmente tem tudo para estar na agenda das organizações brasileiras. 


\section{APÊNDE 4: RESPOSTAS ENTREVISTAS GRUPO 2}

\begin{tabular}{|c|c|}
\hline ENTREVISTADO & RESPOSTA \\
\hline Mariany & $\begin{array}{l}\text { Como eu entrei recentemente, bateu com o momento } \\
\text { que a empresa está implementando o programa, } \\
\text { então, para mim, isso é muito forte lá na empresa. Essa } \\
\text { questão de ser aberto a diversidade. Eu não senti } \\
\text { nenhuma dificuldade, as pessoas são muito abertas, } \\
\text { sempre me receberam muito bem e agora com essa } \\
\text { proposta de diversidade, a empresa está incluindo } \\
\text { mais, está contratando mais mulheres e isso está } \\
\text { sendo incrível. Eu estou vendo a possibilidade de } \\
\text { crescer num ambiente que é majoritariamente } \\
\text { masculino, então está sendo incrível. Já teve } \\
\text { contratação de gerente assistente e quando eu entrei } \\
\text { eu não via isso, só supervisoras de produção, o que já } \\
\text { era um grande avanço. Quando eu entrei como } \\
\text { estagiária eu fazia delas o meu pilar, porque era isso } \\
\text { que eu queria ser. }\end{array}$ \\
\hline Quezia & $\begin{array}{l}\text { Muito boa. Apesar de estar aumentando agora, está } \\
\text { tendo muito mais visibilidade do que tinha antes, então } \\
\text { está sendo feito com maior comunicação do que } \\
\text { estava sendo feito antes, o que é ótimo! }\end{array}$ \\
\hline Saulo & $\begin{array}{l}\text { A Ball vem mudando muito esse paradigma que tem } \\
\text { hoje em dia na sociedade e hoje, a gente tem aqui na } \\
\text { empresa muita mescla nessa questão da diversidade e } \\
\text { isso vem abrindo muito as portas. Antigamente a Ball } \\
\text { era uma empresa muito masculina e hoje a gente já }\end{array}$ \\
\hline
\end{tabular}




\begin{tabular}{|c|c|}
\hline & $\begin{array}{l}\text { tem esse quadro de funcionários bem mesclado e eu } \\
\text { acho isso muito bacana. }\end{array}$ \\
\hline Amanda & $\begin{array}{l}\text { Eu acho que lá é muito interessante, porque a gente vê } \\
\text { muito a questão de igualdade entre homens e } \\
\text { mulheres, a gente vê que as mulheres têm tantas } \\
\text { oportunidades quanto os homens, de trabalhar na } \\
\text { linha, de aprender, de fazer um serviço que em } \\
\text { algumas empresas daqui é única e exclusivamente } \\
\text { masculina. } \\
\text { Quando eu vim para cá, eu tive a percepção de } \\
\text { mercado de trabalho ser muito difícil exatamente por } \\
\text { isso. Eu estudava automação e eu mudei de curso } \\
\text { justamente por medo de não conseguir trabalhar na } \\
\text { área, por ser uma área majoritariamente masculina. Lá } \\
\text { na Ball eu percebi que não é assim. É muito legal ver } \\
\text { que eles abrem essa porta para a gente ter tanto } \\
\text { crescimento quanto os homens no mercado de } \\
\text { trabalho, sabe. }\end{array}$ \\
\hline Vandson & $\begin{array}{l}\text { Esse ano está bem forte a questão da diversidade na } \\
\text { empresa, eu acho muito legal. Ano passado } \\
\text { contratamos muitas mulheres pra trabalhar com a } \\
\text { gente, na área de mecânica, então acho muito bom } \\
\text { esse movimento na empresa, porque antes você falava } \\
\text { de metalúrgica, de indústria e se pensava só em } \\
\text { homens trabalhando, então conforme vai se passando } \\
\text { o tempo, a gente vai engolindo um pouco desse } \\
\text { orgulho que veio dos nossos pais e a gente vai vendo } \\
\text { que tem pessoas extraordinárias por aí que antes não } \\
\text { eram aceitas nesses ambientes. }\end{array}$ \\
\hline Raphael & $\begin{array}{l}\text { Eu sinto que esse engajamento é real e sincero. Eu } \\
\text { sinto uma sinceridade com a forma como essas } \\
\text { questões são tratadas. A empresa se preocupa com } \\
\text { toda sua cadeia de valor também estar engajada, por } \\
\text { exemplo, não ter um fornecedor que explore sua mão }\end{array}$ \\
\hline
\end{tabular}




\begin{tabular}{|c|c|}
\hline & $\begin{array}{l}\text { de obra e que pratique também a diversidade e a } \\
\text { inclusão. }\end{array}$ \\
\hline Nathalia & $\begin{array}{l}\text { Com esse novo programa que a Ball tem feito, eu vejo } \\
\text { que está melhorando muito, ela está trazendo esse } \\
\text { debate para o ambiente de trabalho. A gente participou } \\
\text { da semana de diversidade e inclusão onde diversos } \\
\text { temas foram abordados e foi a primeira vez que eu vi } \\
\text { isso acontecendo de uma forma prática. Mas eu sinto } \\
\text { que isso não chega tanto na produção, fica mais com } \\
\text { o pessoal do administrativo. }\end{array}$ \\
\hline \multicolumn{2}{|c|}{ 2) Você considera esse engajamento importante? Isso motiva você? Por quê? } \\
\hline Mariany & $\begin{array}{l}\text { Extremamente importante. E isso me motiva muito, } \\
\text { exatamente por essa questão. Quando eu cheguei lá e } \\
\text { vi uma supervisora mulher, me deu forças, eu sabia } \\
\text { que eu tinha espaço dentro da empresa e poderia } \\
\text { chegar em algum lugar. }\end{array}$ \\
\hline Quezia & $\begin{array}{l}\text { Sim, importantíssimo. Primeiro porque as pessoas } \\
\text { aprendem a respeitar umas as outras, segundo que a } \\
\text { comunicação entre as pessoas fica muito melhor e } \\
\text { muito mais clara. Quando a pessoa começa a se } \\
\text { colocar no lugar de outras pessoas, ela entende que } \\
\text { aquilo fere, que aquilo dói e que pode acontecer com } \\
\text { ela também. }\end{array}$ \\
\hline Saulo & $\begin{array}{l}\text { Com certeza. A gente tem um caso recente de uma } \\
\text { mulher que virou gerente de planta, então isso não } \\
\text { motiva só a mim, mas principalmente as mulheres. }\end{array}$ \\
\hline Amanda & $\begin{array}{l}\text { Eu não só considero ele importante como eu o } \\
\text { considero essencial. É muito bom você estar em um } \\
\text { ambiente que você vê que terá as mesmas } \\
\text { oportunidades que todo mundo. Porque é muito difícil } \\
\text { as vezes você estar trabalhando em uma empresa e }\end{array}$ \\
\hline
\end{tabular}




\begin{tabular}{|c|c|}
\hline & $\begin{array}{l}\text { pensar, poxa, mas eu gosto tanto de fazer isso, mas eu } \\
\text { não vou ter uma oportunidade porque é uma vaga } \\
\text { masculina. E as vezes eu me daria tão bem quanto um } \\
\text { homem, ainda mais hoje em dia, onde a gente tem } \\
\text { tanta tecnologia. Então acho que seja importante e isso } \\
\text { é uma motivação enorme para mim, de querer estar } \\
\text { naquele ambiente, de querer crescer ali, porque eu sei } \\
\text { que eu vou ter oportunidade, sabe. E eu sei isso tudo } \\
\text { é só o ponto inicial, vão surgir muitas outras coisas e } \\
\text { isso é muito motivador. }\end{array}$ \\
\hline Vandson & $\begin{array}{l}\text { Com certeza motiva, porque a gente sai um pouco do } \\
\text { nosso mundinho, da nossa bolha. Eu tenho } 38 \text { anos, } \\
\text { então a gente ainda tem um pouco daquela pegada de } \\
\text { antigamente, de as coisas serem sempre "certinhas", } \\
\text { mas a gente vê que o mundo tem muito mais coisas } \\
\text { fora dessa bolha, muitas coisas boas e muitas pessoas } \\
\text { que inovam muito, então acredito que essa abertura da } \\
\text { empresa faz todo mundo ganhar. }\end{array}$ \\
\hline Raphael & $\begin{array}{l}\text { Eu considero importante porque eu acho que é bom } \\
\text { você ser treinado a pensar assim e valorizar essas } \\
\text { questões, porque isso te leva a pensar no bem-estar } \\
\text { de todos os funcionários, como controle de carga } \\
\text { horária excessiva, Burnout, entre outros, isso é um } \\
\text { grande motivador também. }\end{array}$ \\
\hline Nathalia & $\begin{array}{l}\text { Muito importante! Nosso país é muito plural e ver a } \\
\text { companhia se importando de abranger a todos de uma } \\
\text { maneira igualitária é muito importante. Eu valorizo } \\
\text { muito e é um dos motivos que eu vi na Ball a empresa } \\
\text { para eu iniciar a minha vida profissional, porque eu } \\
\text { buscava não somente meu desenvolvimento técnico, } \\
\text { mas meu desenvolvimento profissional e mais do que } \\
\text { isso, o meu desenvolvimento pessoal. Eu faço } \\
\text { engenharia, mas antes de estar lidando com número, }\end{array}$ \\
\hline
\end{tabular}




\begin{tabular}{|c|c|}
\hline & $\begin{array}{l}\text { com obras, com cálculos, eu estou lidando com } \\
\text { pessoas, então ter isso dentro da empresa que eu } \\
\text { estou vivenciando diariamente é muito importante e eu } \\
\text { fico muito grata por ter essa oportunidade. }\end{array}$ \\
\hline \multicolumn{2}{|l|}{ 3) } \\
\hline Mariany & $\begin{array}{l}\text { Assim, além de mulher eu sou lésbica, então eu tinha } \\
\text { um pouco de receio por ser fábrica e ter muito homem. } \\
\text { Quando eu entrei eu fiquei muito mais aliviada por ela } \\
\text { ter esse engajamento, porque já encontrei pessoas } \\
\text { parecidas comigo e as pessoas me respeitaram e me } \\
\text { deixaram a vontade. Eu me sentia muito mais a } \\
\text { vontade no trabalho do que na minha própria casa. }\end{array}$ \\
\hline Quezia & $\begin{array}{l}\text { Sim, foi importante sim. Principalmente pelo fato do } \\
\text { respeito. Respeito é uma palavrinha que adulto não } \\
\text { consegue lidar, só criança sabe o que é respeito de } \\
\text { verdade. A gente não sabe se colocar no lugar do } \\
\text { outro, mas uma criança sabe e isso para mim é incrível. } \\
\text { Então quando eu fui procurar o emprego que estou } \\
\text { agora, o fato de a Ball ser uma empresa que respeita } \\
\text { as pessoas, isso foi um grande motivador sim. É um } \\
\text { fator importante você estar em um ambiente em que } \\
\text { tenha confiança de ser quem se é, falar livremente que } \\
\text { as pessoas vão entender e vão respeitar. }\end{array}$ \\
\hline Saulo & $\begin{array}{l}\text { Na verdade, quando eu entrei, há quatro anos, eu não } \\
\text { tinha pensado nisso. Eu tinha uma proposta para entrar } \\
\text { na Ball, que é uma empresa boa e eu já conhecia. } \\
\text { Quando eu mudei de filial e o programa começou a } \\
\text { ficar mais forte, eu comecei a ver de fato essa } \\
\text { diversidade, esse campo que a Ball abriu. Hoje em dia } \\
\text { com certeza eu levaria em consideração. }\end{array}$ \\
\hline
\end{tabular}




\begin{tabular}{|c|c|}
\hline Amanda & $\begin{array}{l}\text { Foi, porque eu jamais na minha imaginei que } \\
\text { conseguiria um estágio lá. Eu estou quase me } \\
\text { formando e eu nunca trabalhei na área, foi meu } \\
\text { primeiro emprego na profissão que eu escolhi. Então } \\
\text { assim, quando eu cheguei lá para fazer a entrevista e } \\
\text { que eu vi como era a empresa, eu fiquei encantada! } \\
\text { Então sim, foi um fator superimportante. }\end{array}$ \\
\hline Vandson & $\begin{array}{l}\text { Olha, eu estou na Ball há } 19 \text { anos, então naquela } \\
\text { época eu não pensava muito sobre isso. Hoje em dia, } \\
\text { eu vejo que as pessoas que entram, principalmente as } \\
\text { mulheres na manutenção, levam isso muito em } \\
\text { consideração e hoje eu levaria também, por tudo que } \\
\text { eu sei e vivencio, vejo o quão importante é trazer essa } \\
\text { diversidade para dentro. }\end{array}$ \\
\hline Raphael & $\begin{array}{l}\text { Eu tenho que admitir que não, porque infelizmente a } \\
\text { gente vive num contexto em que as empresas } \\
\text { manejam o que oferecem de acordo com a busca } \\
\text { econômica delas, então eu busquei um lugar que } \\
\text { primeiramente que me atraísse em outras questões. } \\
\text { Mas desde o primeiro momento a Ball me passou uma } \\
\text { imagem de valorização do funcionário e isso com } \\
\text { certeza foi um fator relevante para eu escolher ficar. }\end{array}$ \\
\hline Nathalia & $\begin{array}{l}\text { Muito! Foi uma das minhas maiores preocupações, de } \\
\text { estar dentro de um lugar que tivesse essa } \\
\text { compatibilidade de valores, de coisas que eu acredito, } \\
\text { porque dizem que a gente é a soma das cinco pessoas } \\
\text { que a gente mais convive e eu não gostaria de estar } \\
\text { convivendo com pessoas que não tivessem essa } \\
\text { compatibilidade. Então sim, foi fundamental. }\end{array}$ \\
\hline \multicolumn{2}{|c|}{$\begin{array}{l}\text { 4) O programa de diversidade da empresa afetou a sua forma de se relacionar com } \\
\text { os outros funcionários e com os clientes externos? }\end{array}$} \\
\hline
\end{tabular}




\begin{tabular}{|c|c|}
\hline Mariany & $\begin{array}{l}\text { O fato de eu saber que tem uma aceitação e um } \\
\text { suporte da empresa, se eu sofrer alguma coisa eu sei } \\
\text { que posso ir ao } \mathrm{RH} \text { e eles vão me ajudar faz eu me } \\
\text { sentir mais leve e tranquila e isso me deixa muito mais } \\
\text { a vontade para me relacionar com as pessoas, sendo } \\
\text { quem eu sou. }\end{array}$ \\
\hline Quezia & $\begin{array}{l}\text { Eu sempre tive isso comigo, eu gosto de dizer que eu } \\
\text { aprendi mais com eles (aqui ela fala sobre a pegada } \\
\text { empática de se relacionar dentro da organização). }\end{array}$ \\
\hline Saulo & $\begin{array}{l}\text { Afetou para a parte boa. Eu senti que com o programa } \\
\text { de diversidade a comunicação ficou mais fluida e } \\
\text { menos estressante, o que melhora a convivência no } \\
\text { dia a dia. }\end{array}$ \\
\hline Amanda & $\begin{array}{l}\text { Eu não tenho muito contato com clientes externos, } \\
\text { então nesse ponto não. Mas com os outros } \\
\text { funcionários sim, porque mesmo eu sendo estagiária, } \\
\text { eu tenho um tratamento muito igual e isso facilita muito } \\
\text { a comunicação, porque você se sente muito a vontade } \\
\text { para se expor, a dar ideias, a mostrar o seu trabalho e } \\
\text { isso acaba melhorando o desempenho, né, porque } \\
\text { você tem espaço para falar, para mostrar o que você } \\
\text { pode fazer e o que você pode agregar. }\end{array}$ \\
\hline Vandson & $\begin{array}{l}\text { Então, não tanto porque eu sempre busquei trabalhar } \\
\text { respeitando todos, mas o conhecimento trouxe mais } \\
\text { clareza para todo mundo, o que eu acredito ter } \\
\text { facilitado a comunicação entre todos nós, } \\
\text { principalmente pela implementação de uma linguagem } \\
\text { nova que facilita o tratamento das pessoas. Ainda mais } \\
\text { a gente que trabalha em um ambiente que tem muito } \\
\text { ruído, então as vezes a gente fala alguma coisa que } \\
\text { pode ser mal interpretado e agora isso facilitou essa } \\
\text { dinâmica. }\end{array}$ \\
\hline
\end{tabular}




\begin{tabular}{|c|c|}
\hline Raphael & $\begin{array}{l}\text { Os ensinamentos que a empresa vem trazendo sobre } \\
\text { diversidade e inclusão me fazem parar para pensar } \\
\text { muito e aprender ainda mais coisas que podem } \\
\text { parecer bobas, mas que no relacionamento diário com } \\
\text { as pessoas fazem muita diferença. E u acho tudo isso } \\
\text { muito importante também porque impacta } \\
\text { positivamente a maneira como você trabalha com } \\
\text { outras empresas. }\end{array}$ \\
\hline Nathalia & $\begin{array}{l}\text { Sim e não. Não, porque já eram coisas que eu } \\
\text { praticava, independente de um programa da empresa. } \\
\text { E sim porque abriu o meu olhar, por exemplo, para } \\
\text { alguns termos que culturalmente eu utilizava e hoje eu } \\
\text { procuro ter mais cuidado na minha comunicação. } \\
\text { Então trouxe esse conhecimento que eu não tinha e } \\
\text { que talvez eu não tivesse se não fosse o programa de } \\
\text { diversidade da fábrica. }\end{array}$ \\
\hline \multicolumn{2}{|c|}{ 5) Como é feita a divulgação desse programa internamente? } \\
\hline Mariany & $\begin{array}{l}\text { Nos portais da Ball e isso é aberto para todo mundo. E } \\
\text { pra quem é da manutenção e não tem esse momento } \\
\text { de parar e entrar nos portais e ver o que eles estão } \\
\text { propondo, eles fizeram um banner de diversidade na } \\
\text { porta de entrada da fábrica e eles sempre colocam nos } \\
\text { murais alguma coisa relacionada ao assunto, então } \\
\text { eles tentam de fato divulgar de todas as formas. }\end{array}$ \\
\hline Quezia & $\begin{array}{l}\text { Aqui a gente faz primeiramente na integração do } \\
\text { funcionário, a gente passa um tempo com ele para } \\
\text { conversar apenas sobre isso, o que está dentro do } \\
\text { nosso código de conduta. Fora a integração a gente } \\
\text { está tendo todos esses movimentos que estão arcados } \\
\text { por agora. }\end{array}$ \\
\hline Saulo & $\begin{array}{l}\text { Além dos e-mails de divulgação de projeto novo e } \\
\text { informação e os grupos de WhatsApp que a gente tem }\end{array}$ \\
\hline
\end{tabular}




\begin{tabular}{|c|c|}
\hline & $\begin{array}{l}\text { da fábrica, existe muita conversa sobre o tema } \\
\text { internamente, fora a integração que o } \mathrm{RH} \text { faz com os } \\
\text { novos funcionários. }\end{array}$ \\
\hline Amanda & $\begin{array}{l}\text { Agora a gente está tendo a semana da diversidade, } \\
\text { então estão tendo reuniões todos os dias, onde o } \\
\text { pessoal expõe as carreiras, o que o programa de } \\
\text { diversidade se propõe a ser desenvolvido. A gente } \\
\text { também sempre recebe conteúdos internos, notícias, } \\
\text { histórias, igual a moça que foi a primeira eletrônica da } \\
\text { empresa que também teve uma divulgação no } \\
\text { Instagram da empresa. No meio corporativo, através } \\
\text { de e-mails, então é dessa forma que eles divulgam, } \\
\text { com muito orgulho de estar dando tantas } \\
\text { oportunidades e de estar abrindo esse caminho. }\end{array}$ \\
\hline Vanson & $\begin{array}{l}\text { Aqui na fábrica tem banners, tem o quadro de avisos, } \\
\text { tem os e-mails. }\end{array}$ \\
\hline Raphael & $\begin{array}{l}\text { É tudo muito embrionário ainda, eu tenho visto essas } \\
\text { preocupações aumentarem agora, mas eu sei que isso } \\
\text { é veiculado pela comunicação interna, através dos e- } \\
\text { mails. Eu imagino que eles vão criar mais espaços e } \\
\text { mais momentos para a gente conversar sobre isso, tem } \\
\text { que ter mais espaço. O pessoal também faz reuniões } \\
\text { via zoom, com debates, discussões etc. }\end{array}$ \\
\hline Nathalia & $\begin{array}{l}\text { As informações que eu recebi foram por e-mail, pelo } \\
\text { WhatsApp, no boca a boca. }\end{array}$ \\
\hline \multicolumn{2}{|c|}{ 6) O que você achou da forma que essa divulgação foi feita? } \\
\hline Mariany & Eu achei importante para chegar em todo mundo. \\
\hline Quezia & $\begin{array}{l}\text { Eu acho ótimo, mas olhando do ponto de vista de como } \\
\text { a gente se comunica com o pessoal aqui, } \\
\text { principalmente ligando com o turno. O administrativo é }\end{array}$ \\
\hline
\end{tabular}




\begin{tabular}{|c|c|}
\hline & $\begin{array}{l}\text { tranquilo porque dá para enquadrar dentro do nosso } \\
\text { dia a dia, agora o turno não, tem o pessoal da noite, o } \\
\text { pessoal do dia e como eles estão lá na linha de } \\
\text { produção, não tem como ficar saindo toda hora. Então } \\
\text { eu acho que poderia fazer de uma forma onde eles } \\
\text { recebessem as informações por WhatsApp, um } \\
\text { método rápido e simples que alcança todo mundo. } \\
\text { Então assim, filtrar tudo o que vai ser passado, } \\
\text { explicando coisas novas que vão surgindo, as } \\
\text { novidades sobre o tema, fazer um compilado disso } \\
\text { tudo para a gente poder enviar para eles. Para mostrar } \\
\text { também que a gente está fazendo algo fora do horário } \\
\text { de trabalho deles, que tem algo fluindo ali, novidades } \\
\text { etc. Então passar dessa forma, não só colocar no } \\
\text { mural ou só mandar uma foto, mas fazer um vídeo } \\
\text { também, um compilado disso tudo. }\end{array}$ \\
\hline Saulo & Eu acho interessante porque alcança todo mundo. \\
\hline Amanda & $\begin{array}{l}\text { Eu acho muito legal porque chega em todo mundo. A } \\
\text { gente que é colaborador, claro, segue a empresa nas } \\
\text { redes sociais, a gente tem o e-mail corporativo onde } \\
\text { recebemos as notícias todos os dias, então foi bem } \\
\text { abrangente e todo mundo tem acesso, todo mundo fica } \\
\text { sabendo. }\end{array}$ \\
\hline Vandson & $\begin{array}{l}\text { Eu acredito que essa divulgação alcança todo mundo, } \\
\text { mas eu acho que deveria falar mais um pouco, porque } \\
\text { a gente que está no administrativo consegue participar } \\
\text { das reuniões, dos eventos etc., mas eu não sei como } \\
\text { isso chega na fábrica. Acredito que nas reuniões de } \\
\text { passagem de turno acabam falando, mas assim, eu } \\
\text { acho que para pra gente mudar uma cultura é muito } \\
\text { difícil, então deveria ter mais constância também na } \\
\text { fábrica para conquistar cada vez mais espaço e mais } \\
\text { rápido. }\end{array}$ \\
\hline
\end{tabular}




\begin{tabular}{|c|c|}
\hline Raphael & $\begin{array}{l}\text { Eu acho que é uma boa forma de fazer, tem que ter } \\
\text { cara a cara, tem que ter conversa. Eu acho que essa } \\
\text { comunicação está boa, adequada ao momento e está } \\
\text { passando o recado bem. }\end{array}$ \\
\hline Nathalia & $\begin{array}{l}\text { Eu achei que pudesse ser de forma mais assertiva de } \\
\text { modo que atingisse mais pessoas, que não ficasse } \\
\text { limitado ao administrativo. }\end{array}$ \\
\hline \multicolumn{2}{|c|}{$\begin{array}{l}\text { 7) Como é feita a divulgação desse programa externamente? Condiz com a realidade } \\
\text { do que é praticado internamente? }\end{array}$} \\
\hline Mariany & $\begin{array}{l}\text { Eu realmente não sei muito bem, mas acredito que } \\
\text { pelo site da empresa e nas mídias mesmo. }\end{array}$ \\
\hline Quezia & $\begin{array}{l}\text { Eu não sei como isso é feito externamente, porque aqui } \\
\text { a gente está muito acostumado a usar a nossa página, } \\
\text { o Ball conecta, que é interna. Eu não costumo olhar o } \\
\text { site da empresa. Então a gente tem muito mais } \\
\text { informação que as outras pessoas. }\end{array}$ \\
\hline Saulo & $\begin{array}{l}\text { Realmente não sei, a Ball ainda não faz muita } \\
\text { propaganda sobre esse tema, eles estão muito mais } \\
\text { focados internamente. }\end{array}$ \\
\hline Amanda & $\begin{array}{l}\text { Eu não sei como é feita externamente, mas pelas redes } \\
\text { sociais condiz totalmente. }\end{array}$ \\
\hline Vandson & $\begin{array}{l}\text { Eu vi alguns dias no Linkedln a divulgação das vagas } \\
\text { para supervisão de manutenção e outras áreas da } \\
\text { fábrica com uma linguagem totalmente diferente, } \\
\text { abrindo muito mais espaço para as mulheres. }\end{array}$ \\
\hline
\end{tabular}




\begin{tabular}{|c|c|}
\hline Raphael & $\begin{array}{l}\text { Eu vejo muito pelo Linkedln e acredito que esteja } \\
\text { alinhada sim com a forma que é praticada } \\
\text { internamente sim. }\end{array}$ \\
\hline Nathalia & $\begin{array}{l}\text { Agora que existe um setor específico de diversidade e } \\
\text { inclusão, eu vejo isso sendo divulgado nos processos } \\
\text { seletivos e na divulgação das vagas pelo Linkedln. } \\
\text { Eles estão fazendo processo seletivo direcionado, para } \\
\text { aumentar a quantidade de mulheres atuando na } \\
\text { fábrica, aumentar a quantidade de PCDs e capacitá-los } \\
\text { e isso está sendo divulgado nas redes sociais, então } \\
\text { acaba sendo direcionado tanto de forma ampla como } \\
\text { direcionada para um público. }\end{array}$ \\
\hline \multicolumn{2}{|c|}{ 8) Existe algum tipo de treinamento e sensibilização à diversidade na empresa? } \\
\hline Mariany & $\begin{array}{l}\text { Eu nunca participei por ter pouco tempo na empresa, } \\
\text { mas tem a integração que não deixa de ser um } \\
\text { treinamento para quem está entrando na empresa. }\end{array}$ \\
\hline Quezia & $\begin{array}{l}\text { Sim, a própria integração, e as informações são } \\
\text { compartilhadas com eles frequentemente. Até terminar } \\
\text { todo o projeto, acho que ainda não temos algo } \\
\text { totalmente estruturado, mas a gente costuma usar } \\
\text { algumas datas específicas, como o dia da mulher, o } \\
\text { Dia das Mães para levar informações importantes aos } \\
\text { funcionários, como a inclusão da mulher na sociedade, } \\
\text { a história por trás das datas e os direitos do cidadão. } \\
\text { Então a gente vai unindo o útil ao agradável para trazer } \\
\text { o máximo de informação possível. }\end{array}$ \\
\hline Saulo & $\begin{array}{l}\text { Sim e vai ter semana que vem, a semana da } \\
\text { diversidade, de segunda a sexta e o } \mathrm{RH} \text { vai ministrar } \\
\text { esse treinamento. Então existe com alguma frequência } \\
\text { eventos como esse. }\end{array}$ \\
\hline
\end{tabular}




\begin{tabular}{|c|c|}
\hline Amanda & $\begin{array}{l}\text { Então, foi como eu te falei, está tendo agora a semana } \\
\text { da diversidade, que é como uma reunião, uma } \\
\text { palestra, mas acredito que pode ser considerado um } \\
\text { treinamento, porque eles estão falando como vai ser, a } \\
\text { postura da Ball diante dessa questão. }\end{array}$ \\
\hline Vandson & $\begin{array}{l}\text { Para sensibilização eles estão fazendo esses eventos } \\
\text { com temas sobre diversidade, inclusão e outras coisas. }\end{array}$ \\
\hline Raphael & $\begin{array}{l}\text { Não que eu saiba. Talvez isso possa surgir. Mas assim } \\
\text { que você entra na empresa, o pessoal apresenta os } \\
\text { canais de contato caso você precise de suporte, os } \\
\text { núcleos de representação à diversidade que existe e } \\
\text { tudo que é feito sobre o tema na empresa. }\end{array}$ \\
\hline Nathalia & $\begin{array}{l}\text { Eu nunca fiz, tirando a semana da diversidade. Mas } \\
\text { aconteceu uma mobilização para trazer temas que são } \\
\text { abordados no nosso dia a dia voltados para } \\
\text { diversidade e inclusão. }\end{array}$ \\
\hline \multicolumn{2}{|c|}{$\begin{array}{l}\text { 9) Existiu "reciclagem" sobre algum procedimento interno após a implementação do } \\
\text { programa de diversidade na empresa? }\end{array}$} \\
\hline Mariany & Aqui na minha área. Por enquanto não. \\
\hline Quezia & $\begin{array}{l}\text { Sim, existem alguns treinamentos de reciclagem mais } \\
\text { para quem está dentro do administrativo. }\end{array}$ \\
\hline Saulo & $\begin{array}{l}\text { Sim, muita coisa foi adaptada. O ambiente era muito } \\
\text { masculinizado, então era diferente a maneira de lidar e } \\
\text { isso precisou ser adaptado também. }\end{array}$ \\
\hline Amanda & $\begin{array}{l}\text { Por enquanto ainda não, como eu falei, aqui os } \\
\text { processos funcionam de forma bem fluída com uma } \\
\text { comunicação muito fácil entre os funcionários, então } \\
\text { não houve nenhuma adaptação de processo na minha } \\
\text { área. }\end{array}$ \\
\hline
\end{tabular}




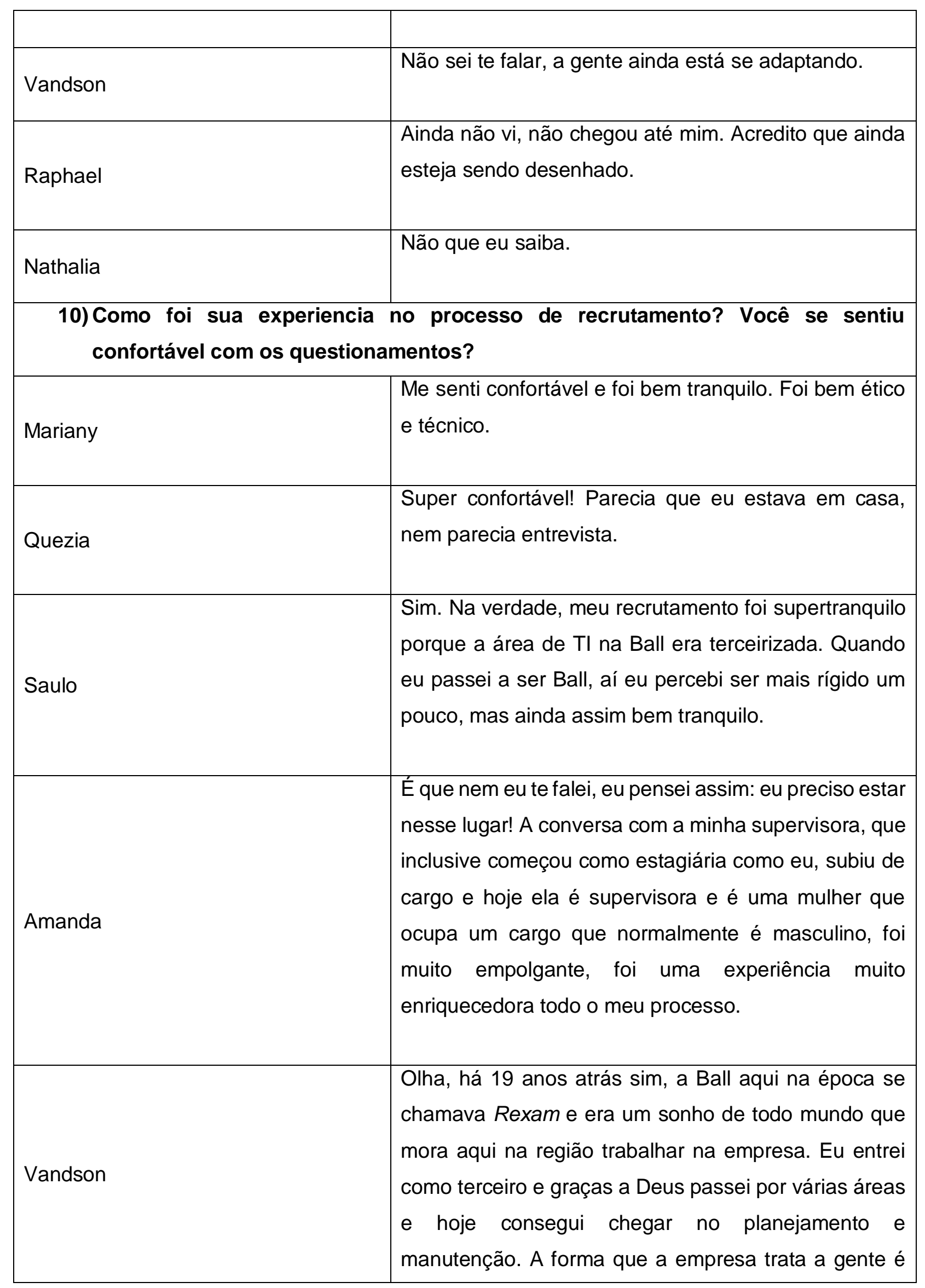




\begin{tabular}{|c|l|}
\hline & $\begin{array}{l}\text { muito boa e eu só vi melhorando com o tempo, nada } \\
\text { regrediu. }\end{array}$ \\
\hline Raphael & $\begin{array}{l}\text { Me senti confortável, não senti nenhuma } \\
\text { discriminação, nenhum tratamento diferente e eu senti } \\
\text { uma fala muito forte de valorização das pessoas. }\end{array}$ \\
\hline Nathalia & $\begin{array}{l}\text { Eu me senti muito confortável, as meninas foram } \\
\text { incríveis. Desde a primeira comunicação até o } \\
\text { momento da resposta final eu me senti muito bem e } \\
\text { acolhida. }\end{array}$ \\
\hline 11) Fizeram alguma pergunta \\
\hline demográficas, como gênero, idade, endereço etc.?
\end{tabular}




\begin{tabular}{|c|c|}
\hline & $\begin{array}{l}\text { a gente a gente bate record de linha, ganhamos } \\
\text { presentes. E, além disso, recebemos e-mails } \\
\text { motivacionais sobre nosso esforço e isso não acontece } \\
\text { só quando batemos metas. Meu chefe, por exemplo, } \\
\text { sempre dá muito apoio e motivação para a equipe, } \\
\text { agradecendo muito pelo nosso trabalho e pelo que } \\
\text { fazemos a mais. }\end{array}$ \\
\hline Quezia & $\begin{array}{l}\text { A Ball tem uma política muito regrada para as } \\
\text { atividades, seguindo um padrão para todas as } \\
\text { unidades, até porque somos todos one Ball. Mas } \\
\text { quando a gente bate um record mensal, por exemplo, } \\
\text { a gente tem um almoço especial, parabenizando a } \\
\text { todos }\end{array}$ \\
\hline Saulo & $\begin{array}{l}\text { Sim, a gente tem reconhecimento por tempo de casa, } \\
\text { metas de produção. Sempre que a gente bate um } \\
\text { record a empresa dá almoço especial, brindes e } \\
\text { eventos. A empresa reconhece bastante. }\end{array}$ \\
\hline Amanda & $\begin{array}{l}\text { Ah, bastante. Além do financeiro, como premiações e } \\
\text { tal, a gente sempre é comunicado quando acontece } \\
\text { alguma coisa muito importante. Se você fez parte de } \\
\text { algum projeto que se destacou, eles comunicam no } \\
\text { meio corporativo. Ou quando acontece algum fato, } \\
\text { como primeira mulher a ocupar certo cargo, estagiário } \\
\text { que cresceu mais rápido, enfim, eles sempre colocam } \\
\text { isso em evidência, sabe. E não só o corporativo, a } \\
\text { gerência onde eu trabalho, eles estão sempre além da } \\
\text { crítica, eles sempre elogiam, apontam as coisas boas, } \\
\text { sempre estão dispostos a andar junto com você. }\end{array}$ \\
\hline Vandson & $\begin{array}{l}\text { Tem um programa que chama "Thank you", tinha o } \\
\text { programa da latinha, que você uma latinha por e-mail, } \\
\text { e são agradecimentos, onde você reconhecia aquela } \\
\text { pessoa e aí no final do ano você ia juntando aquela }\end{array}$ \\
\hline
\end{tabular}




\begin{tabular}{|c|c|}
\hline & $\begin{array}{l}\text { pontuação e no final do ano, na confraternização, o RH } \\
\text { te premiava com um troféu. Eu já ganhei uns } 5 \text { desses. }\end{array}$ \\
\hline Raphael & $\begin{array}{l}\text { Existem prêmios por tempo de serviço, qualidade de } \\
\text { atendimento, pessoas que fizeram diferencial. <as } \\
\text { ainda é tudo voltado para a questão operacional e } \\
\text { resultado técnico. }\end{array}$ \\
\hline Nathalia & $\begin{array}{l}\text { Eu sei que existem os "thank yous" que é para } \\
\text { promover esse reconhecimento entre a galera. Eu, } \\
\text { Nathalia, tive duas experiencias muito legais lá dentro, } \\
\text { que foi uma publicação de um colega de trabalho no } \\
\text { Linkedln, reconhecendo meu trabalho e, o que mais } \\
\text { me surpreendeu, foi na parada anual de manutenção, } \\
\text { um analista veio com um cartãozinho e uma caixinha } \\
\text { de bombom agradecendo por eu ter contribuído com a } \\
\text { parada anual e pode parecer uma bobeira, mas te } \\
\text { motiva, eu fico grata pelo meu trabalho ter contribuído } \\
\text { por um momento tão importante da empresa. }\end{array}$ \\
\hline \multicolumn{2}{|c|}{ 13) De que forma você sente seu trabalho sendo valorizado na empresa? } \\
\hline Mariany & $\begin{array}{l}\text { Esse é meu primeiro trabalho na manutenção, antes eu } \\
\text { trabalhava com assistência técnica, placas eletrônicas, } \\
\text { coisas muito pequenas. Agora eu mexo com motor } \\
\text { gigante e tem dois meses que eu sinto as pessoas } \\
\text { valorizando meu trabalho e eu sinto orgulho disso, eu } \\
\text { tendo a oportunidade de operar máquinas tão grandes } \\
\text { em um processo superimportante e delicado. As } \\
\text { pessoas me enxergam como importante ali e isso faz } \\
\text { eu me sentir muito bem. Então na produção eu sinto } \\
\text { isso, meu trabalho sendo valorizado pelo } \\
\text { reconhecimento. }\end{array}$ \\
\hline Quezia & $\begin{array}{l}\text { Os meus feedbacks são muito bons e isso me motiva } \\
\text { muito. }\end{array}$ \\
\hline
\end{tabular}




\begin{tabular}{|c|c|}
\hline Saulo & $\begin{array}{l}\text { Tem um sistema na Ball, como se fosse um Facebook } \\
\text { da empresa, e nesse ambiente a gente consegue dar } \\
\text { cards, então quando alguém faz um serviço bacana e } \\
\text { que você fica agradecido e quer mostrar para essa } \\
\text { pessoa, você dá um "thank you" através do sistema. } \\
\text { Antigamente esses "thank you's" eram dados através } \\
\text { de cartõezinhos. E a gente troca muito aqui, isso faz eu } \\
\text { sentir meu trabalho sendo reconhecido. }\end{array}$ \\
\hline Amanda & $\begin{array}{l}\text { Para mim, Amanda, são as oportunidades. Você ser } \\
\text { elogiado e você ser cotado, por exemplo, falarem que } \\
\text { você está indo bem, quando surge uma oportunidade } \\
\text { você estar em evidência. Para mim, esse é o ponto } \\
\text { primordial. }\end{array}$ \\
\hline Vandson & $\begin{array}{l}\text { Então, a gente tem feedbacks, né. Eu particularmente } \\
\text { com a minha supervisora tenho feedbacks quase toda } \\
\text { semana e eu acho isso muito bom. Mas na Ball, a cada } \\
\text { seis meses a gente faz avaliação e o nosso supervisor } \\
\text { mostra pra gente onde estamos, onde queremos } \\
\text { chegar e os passos que devemos seguir, aí você sabe } \\
\text { se esta no caminho certo ou não. E aqui isso funciona } \\
\text { muito rápido, então se você fez alguma coisa errada, } \\
\text { você já vai saber e já é direcionado para o caminho } \\
\text { correto, isso para mim, é ter meu trabalho sendo } \\
\text { valorizado. }\end{array}$ \\
\hline Raphael & $\begin{array}{l}\text { Olha, isso é até uma questão emocional para mim. Eu } \\
\text { vim para cá porque eu acreditava e eu acredito na } \\
\text { empresa e eu sinto meu trabalho muito valorizado, } \\
\text { porque eu acredito no que eu faço, no meu potencial e } \\
\text { a empresa reconhece isso. Mas eu gostaria de um } \\
\text { incentivo financeiro maior. }\end{array}$ \\
\hline Nathalia & $\begin{array}{l}\text { Mais do que essas gratificações como almoços de } \\
\text { records, para mim, foi uma surpresa muito grande }\end{array}$ \\
\hline
\end{tabular}




\begin{tabular}{|c|c|}
\hline & $\begin{array}{l}\text { quando a vaga de analista abriu e várias pessoas, } \\
\text { pessoas que eu não imaginava, vieram me motivar a } \\
\text { tentar a efetivação, elogiando meu trabalho e dizendo } \\
\text { que eu tenho capacidade. Eu tinha o feedback dos } \\
\text { meus gestores, mas ouvir isso de outras pessoas que } \\
\text { não trabalhavam diretamente comigo foi bem } \\
\text { surpreendente. Eu me senti importante! }\end{array}$ \\
\hline \multicolumn{2}{|c|}{$\begin{array}{l}\text { 14) Você acredita que a empresa traz no seu dia a dia o que prega sobre diversidade } \\
\text { e inclusão? }\end{array}$} \\
\hline Mariany & $\begin{array}{l}\text { Sim, todos os dias eu sou tratada com respeito e } \\
\text { profissionalismo e a empresa está sempre presente } \\
\text { informando e passando conteúdo sobre diversidade. }\end{array}$ \\
\hline Quezia & Sim! \\
\hline Saulo & $\begin{array}{l}\text { Sim, a gente vê até pela mudança no quadro de } \\
\text { funcionários. }\end{array}$ \\
\hline Amanda & $\begin{array}{l}\text { Traz sim, bastante. Eu não conheço as outras plantas, } \\
\text { mas onde eu estou é visível isso, tanto que eu falo que } \\
\text { a gente se sente acolhido. }\end{array}$ \\
\hline Vandson & $\begin{array}{l}\text { Eu acredito que sim, mesmo antes de começar esse } \\
\text { projeto ela já pregava muito isso e a gente já vivia muito } \\
\text { disso também. }\end{array}$ \\
\hline Raphael & $\begin{array}{l}\text { Totalmente, lá eu vejo que é de verdade. Todo dia é } \\
\text { um aprendizado novo na própria relação com as } \\
\text { pessoas. }\end{array}$ \\
\hline Nathalia & $\begin{array}{l}\text { Sim, é o que eu estava te falando. A gente tem muita } \\
\text { coisa para melhorar, mas você vê no dia a dia essa } \\
\text { cultura acontecendo, sabe. }\end{array}$ \\
\hline
\end{tabular}




\begin{tabular}{|c|c|}
\hline Mariany & $\begin{array}{l}\text { Ainda é meu primeiro ano, por isso ainda não tive } \\
\text { avaliação de desempenho. Eu vou ter agora no fim do } \\
\text { ano. Mas pelo que eu observei de outros } \\
\text { colaboradores é uma avaliação muito justa, onde a } \\
\text { gente pode dar nossa opinião também e onde todos os } \\
\text { pontos são respondidos de forma coerente, então } \\
\text { acredito que isso conte bastante para a trilha de } \\
\text { carreira do funcionário. }\end{array}$ \\
\hline Quezia & $\begin{array}{l}\text { Muito! A avaliação é um dos focos para a trilha de } \\
\text { carreira do colaborador. O que acreditamos ser justo, } \\
\text { porque uma balança ela não pode pesar de um lado } \\
\text { só, tem que ter um equilíbrio, então funcionário e } \\
\text { empresa têm que andar juntos. }\end{array}$ \\
\hline Saulo & $\begin{array}{l}\text { Sim, inclusive existe um portal da Ball onde tem as } \\
\text { metas que o supervisor de cada área tem e quando } \\
\text { você bate essa meta, o supervisor avalia e te dá um } \\
\text { feedback por ali. Depois existe uma conversa de } \\
\text { avaliação e de agradecimento. }\end{array}$ \\
\hline Amanda & $\begin{array}{l}\text { Eu acredito que sim, mas eu não tenho certeza porque } \\
\text { eu não cheguei a fazer ainda. Eu sei que acontece todo } \\
\text { ano, mas eu não sei te dizer como funciona. Mas eu } \\
\text { tenho certeza de que a empresa leva isso em } \\
\text { consideração na trajetória dos funcionários. }\end{array}$ \\
\hline Vandson & $\begin{array}{l}\text { Sim, ali você tem uma pontuação e se você já está com } \\
\text { o salário no teto, você recebe um bônus de acordo com } \\
\text { a pontuação na avaliação. Aí tem uma reunião do } \\
\text { comitê, com supervisores e a nossa gestora de } \mathrm{RH} \text { que } \\
\text { fazem toda essa avaliação. }\end{array}$ \\
\hline Raphael & $\begin{array}{l}\text { São sim, mas a Ball não tem bem um plano de carreira } \\
\text { e acho isso muito importante, ainda mais para uma } \\
\text { empresa que vive diversidade e inclusão. }\end{array}$ \\
\hline
\end{tabular}




\begin{tabular}{|c|c|}
\hline Nathalia & $\begin{array}{l}\text { Eu não sei te responder, porque estagiário não faz } \\
\text { avaliação de desempenho. A gente faz sessões de } \\
\text { feedbacks e acredito que isso conte muito para a } \\
\text { efetivação. }\end{array}$ \\
\hline \multicolumn{2}{|c|}{ 16) Quais setores da empresa são responsáveis pelo programa de diversidade? } \\
\hline Mariany & $\begin{array}{l}\text { Eu sei que tem a área de comunicação que trabalha } \\
\text { muito isso, o } \mathrm{RH} \text { também e tem a área de } \mathrm{D} \& \mathrm{l}, \\
\text { responsável para tratar as demandas do programa de } \\
\text { diversidade. }\end{array}$ \\
\hline Quezia & Recursos Humanos e Comunicação. \\
\hline Saulo & $\begin{array}{l}\text { Eu vejo muito o } \mathrm{RH} \text { e comunicação. Não lembro de } \\
\text { outro setor divulgando. Tem o corporativo também. }\end{array}$ \\
\hline Amanda & $\begin{array}{l}\text { Não tenho certeza, mas sei dizer que o RH faz parte. } \\
\text { Eu sei que tem a área de Diversidade e Inclusão que } \\
\text { foi criada recentemente, eu acho. }\end{array}$ \\
\hline Vandson & $\begin{array}{l}\text { O nosso } \mathrm{RH} \text {, mas a gente sabe também que ele não } \\
\text { trabalha sozinha, então ele precisa do nosso apoio } \\
\text { como funcionário e tem as pessoas a frente desse } \\
\text { projeto de diversidade. }\end{array}$ \\
\hline Raphael & $\begin{array}{l}\text { Rh, comunicação e acredito que tenha uma área só de } \\
\text { diversidade e inclusão, se não me engano. }\end{array}$ \\
\hline Nathalia & $\begin{array}{l}\text { Eu sei que tem um núcleo específico que trabalha junto } \\
\text { com o } \mathrm{RH} \text {. }\end{array}$ \\
\hline \multicolumn{2}{|c|}{$\begin{array}{l}\text { 17) Você já trabalhou em alguma outra empresa que não tinha programa de } \\
\text { diversidade? Notou alguma diferença na comunicação da empresa com seus } \\
\text { clientes internos (funcionários) e externos? }\end{array}$} \\
\hline
\end{tabular}




\begin{tabular}{|c|c|}
\hline Mariany & $\begin{array}{l}\text { Sim. Era uma empresa familiar, não tinha a estrutura } \\
\text { que a Ball tem e o foco deles era apenas produção. } \\
\text { Não se falava sobre diversidade, sobre pessoas e } \\
\text { infelizmente o RH era muito fraco, a gente não se } \\
\text { sentia confortável de chegar até eles. }\end{array}$ \\
\hline Quezia & $\begin{array}{l}\text { Todas as empresas que eu trabalhei tinham programa } \\
\text { de diversidade e inclusão. Só uma que era uma } \\
\text { contabilidade bem pequenininha, que ela não tinha um } \\
\text { programa estruturado, mas havia respeito entre as } \\
\text { pessoas independente de quem fosse. }\end{array}$ \\
\hline Saulo & $\begin{array}{l}\text { Eu sempre trabalhei em órgão público e escolas, o que } \\
\text { é muito mesclado, então não tenho muito parâmetro, } \\
\text { tirando pela comunicação que na Ball é bem mais } \\
\text { fluída. }\end{array}$ \\
\hline Amanda & $\begin{array}{l}\text { É que assim, são setores totalmente diferentes, então } \\
\text { eu tenho uma certa dificuldade em comparar. Mas, em } \\
\text { uma perspectiva de inclusão e diversidade eu já } \\
\text { trabalhei em alguns lugares que me decepcionaram } \\
\text { muito que, inclusive, eu saí por esse motivo. Teve uma } \\
\text { época que eu trabalhei em uma farmácia aqui da } \\
\text { região, e eu já tinha bastante experiência na área, } \\
\text { porque eu já tinha trabalhado por dois anos em outra } \\
\text { farmácia, e o meu chefe surtou comigo porque eu tinha } \\
\text { colocado um piercing, sabe. E eu achei isso muito } \\
\text { antiético, porque não teve uma conversa, uma } \\
\text { comunicação clara, ele foi totalmente agressivo e } \\
\text { desrespeitoso. E na Ball eu sei que nunca aconteceria } \\
\text { isso, eu sei que eu seria chamada caso infringisse } \\
\text { alguma regra da empresa, mas eu não seria } \\
\text { desrespeitada. }\end{array}$ \\
\hline
\end{tabular}




\begin{tabular}{|l|l|}
\hline Vandson & $\begin{array}{l}\text { Eu sempre trabalhei na Ball, aqui foi meu primeiro } \\
\text { emprego e eu nunca mais saí, então não tenho uma } \\
\text { regra de comparação. }\end{array}$ \\
\hline Raphael & $\begin{array}{l}\text { Eu já estive em uma empresa multinacional de grande } \\
\text { porte que tem um programa de diversidade e não vive } \\
\text { isso no seu dia a dia, é totalmente de fachada. A } \\
\text { comunicação em uma empresa que vive de verdade } \\
\text { isso é totalmente diferente, é um ambiente mais } \\
\text { respeitoso onde você se sente confortável de se } \\
\text { comunicar e dar as suas ideias sem ter medo de ser } \\
\text { hostilizado. } \\
\text { A empresa que eu trabalhava já tinha toda uma } \\
\text { estrutura e a Ball ainda está se estruturando nesse } \\
\text { aspecto, mas está muito a frente dessa empresa. }\end{array}$ \\
\hline Nathalia & $\begin{array}{l}\text { Aqui é meu primeiro emprego, mas eu tenho } \\
\text { experiências acadêmicas, como empresa júnior etc., e } \\
\text { com essas experiências na graduação eu vejo que faz } \\
\text { muita diferença estar em um ambiente que vive a inclusão, porque a minha universidade } \\
\text { diversidape super elitizado. }\end{array}$ \\
\hline
\end{tabular}

